\title{
A consistent global approach for the morphometric characterization of subaqueous landslides
}

MICHAEL CLARE ${ }^{1 *}$, JASON CHAYTOR ${ }^{2}$, OLIVER DABSON $^{3}$,

DAVIDE GAMBOA ${ }^{4}$, AGGELIKI GEORGIOPOULOU ${ }^{5}$, HARRY EADY $^{6}$, JAMES HUNT ${ }^{1}$, CHRISTOPHER JACKSON 7 , ODED KATZ ${ }^{8}$, SEBASTIAN KRASTEL ${ }^{9}$, RICARDO LEÓN ${ }^{10}$, AARON MICALLEF ${ }^{11}$, JASPER MOERNAUT ${ }^{12}$, ROBERTO MORICONI ${ }^{13,14}$, LORENA MOSCARDELLI $^{15}$, CHRISTOF MUELLER ${ }^{16}$, ALEXANDRE NORMANDEAU ${ }^{17}$, MARCO PATACCI ${ }^{18}$, MICHAEL STEVENTON ${ }^{7}$, MORELIA URLAUB ${ }^{19}$, DAVID VÖLKER ${ }^{20}$, LESLI WOOD $^{21} \&$ ZANE JOBE ${ }^{21}$

${ }^{1}$ National Oceanography Centre, University of Southampton Waterfront Campus, European Way, Southampton SO14 3ZH, UK

${ }^{2}$ United States Geological Survey, 384 Woods Hole Road, Woods Hole, MA 02543, USA

${ }^{3}$ CH2M, Elms House, 43 Brook Green, London W6 7EF, UK

${ }^{4}$ British Geological Survey, Cardiff University, Main Building, Park Place, Cardiff CF10 3AT, UK

${ }^{5}$ UCD School of Earth Sciences, University College Dublin, Dublin, Ireland

${ }^{6}$ Fugro GeoServices Limited, Fugro House, Hithercroft Road, Wallingford, Oxfordshire OX10 9RB, UK

${ }^{7}$ Basins Research Group (BRG), Department of Earth Science \& Engineering, Imperial College, Prince Consort Road, London SW72BP, UK

${ }^{8}$ Geological Survey of Israel, Jerusalem, Israel

${ }^{9}$ Cluster of Excellence: The Future Ocean, Christian-Albrechts-Universität zu Kiel, Leibniz Institute of Marine Sciences (IFM-GEOMAR), Kiel, Germany

${ }^{10}$ IGME, Geological Survey of Spain, C/Rios Rosas 23, 28003, Madrid, Spain

${ }^{11}$ Marine Geology and Seafloor Surveying, Department of Geosciences, University of Malta, Msida, MSD 2080, Malta

${ }^{12}$ Institute of Geology, University of Innsbruck, Innrain 52, Innsbruck, Austria

${ }^{13}$ Fugro Oceansismica S.P.A., 268 Viale Lenormant Charles, Roma, RM 00126, Italy

${ }^{14}$ Present address: National Oceanography Centre, University of Southampton Waterfront Campus, European Way, Southampton SO14 3ZH, UK

${ }^{15}$ Statoil Research and Technology, 6300 Bridge Point Parkway, Austin, TX 78730, USA

${ }^{16}$ GNS Science, Lower Hutt, New Zealand

From: Lintern, D. G., Mosher, D. C., Moscardelli, L. G., Bobrowsky, P. T., Campbell, C., Chaytor, J. D., Clague, J. J., Georgiopoulou, A., Lajeunesse, P., Normandeau, A., Piper, D. J. W., Scherwath, M., Stacey, C. \& Turmel, D. (eds) Subaqueous Mass Movements. Geological Society, London, Special Publications, 477, https://doi.org/10.1144/SP477.15 


\title{
M. CLARE ET AL
}

${ }^{17}$ Geological Survey of Canada - Atlantic, Bedford Institute of Oceanography, Dartmouth, Canada

${ }^{18}$ Institute of Applied Geoscience, School of Earth and Environment, University of Leeds, Leeds LS2 9JT, UK

${ }^{19}$ GEOMAR Helmholtz Centre for Ocean Research Kiel, 24148, Kiel, Germany

${ }^{20}$ Marum - Zentrum für Marine Umweltwissenschaften, der Universität Bremen, Postfach 330 440, 28334, Bremen, Germany

${ }^{21}$ Department of Geology and Geological Engineering, Colorado School of Mines, 1500 Illinois Street, Golden, CO 80401, USA

*Correspondence: m.clare@noc.ac.uk

\begin{abstract}
Landslides are common in aquatic settings worldwide, from lakes and coastal environments to the deep sea. Fast-moving, large-volume landslides can potentially trigger destructive tsunamis. Landslides damage and disrupt global communication links and other critical marine infrastructure. Landslide deposits act as foci for localized, but important, deep-seafloor biological communities. Under burial, landslide deposits play an important role in a successful petroleum system. While the broad importance of understanding subaqueous landslide processes is evident, a number of important scientific questions have yet to receive the needed attention. Collecting quantitative data is a critical step to addressing questions surrounding subaqueous landslides.

Quantitative metrics of subaqueous landslides are routinely recorded, but which ones, and how they are defined, depends on the end-user focus. Differences in focus can inhibit communication of knowledge between communities, and complicate comparative analysis. This study outlines an approach specifically for consistent measurement of subaqueous landslide morphometrics to be used in the design of a broader, global open-source, peer-curated database. Examples from different settings illustrate how the approach can be applied, as well as the difficulties encountered when analysing different landslides and data types. Standardizing data collection for subaqueous landslides should result in more accurate geohazard predictions and resource estimation.
\end{abstract}

\section{The importance of subaqueous landslides for society, economy and ecology}

Terrestrial landslides are important agents for the transport of sediment and organic carbon (Korup et al. 2007; Hilton et al. 2008). They can dramatically modify landscapes and ecosystems (Keefer 1984; Swanson et al. 1988; Walker et al. 2009), and pose a hazard to critical infrastructure and human life (Petley 2012). High-resolution and regular satellite mapping, real-time monitoring, personal accounts, news reports, and even social media trends are used to record terrestrial landslide activity, thus providing valuable and temporally-constrained information that forms the basis of extensive landslide databases and catalogues (Malamud et al. 2004; Petley et al. 2005; Korup et al. 2007; Kirschbaum et al. 2010; Petley 2012; Klose et al. 2014; Pennington et al. 2015; Taylor et al. 2015). These databases can be interrogated to quantify preconditioning and triggering mechanisms, understand risk profiles for different regions, assess the extent and nature of ancient events, calibrate numerical models of slope stability, and inform forecasts of future landslide activity. Indeed, many countries now have operational real-time terrestrial landslide forecast systems in place (e.g. Chen \& Lee 2004; Baum \& Godt 2010).
Landslides that occur in subaqueous settings (ranging from lakes and coastal regions to the deep sea) are also societally, economically and ecologically important, yet our understanding of them is much less well developed than for their onshore equivalents (Talling et al. 2014). Subaqueous landslides can be many orders of magnitude larger than terrestrial landslides (Korup et al. 2007), transporting up to thousands of cubic kilometres of sediment (Moore et al. 1989, 1994; Watts \& Masson 1995; Collot et al. 2001; Haflidason et al. 2004; Masson et al. 2006; Day et al. 2015) and large volumes of exhumed organic carbon (St-Onge \& HillaireMarcel 2001; Smith et al. 2015; Azpiroz-Zabala et al. 2017). Submarine and sublacustrine landslides often generate long runout flows, which damage strategically important seafloor infrastructure including telecommunication cables, production platforms and hydrocarbon pipelines (Piper et al. 1999; Mosher et al. 2010b; Thomas et al. 2010; Carter et al. 2014; Forsberg et al. 2016; Pope et al. 2017). Tsunamis generated by subaqueous landslides threaten many coastal communities and have caused large numbers of fatalities (Tappin et al. 2001; Ward 2001; Harbitz et al. 2014). Low-lying Small Island Developing States, such as those in the South Pacific, are particularly at risk from locally-sourced tsunamis, but little 


\section{MORPHOMETRICS OF SUBAQUEOUS LANDSLIDES}

is currently known about the scale, location and recurrence of tsunamigenic landslides in those areas (Goff \& Terry 2016). Under burial, subaqueous landslide deposits are recognized as an important element of hydrocarbon systems: conditioning reservoir distribution (Armitage et al. 2009; Kneller et al. 2016), acting as seals (Cardona et al. 2016) and as potential reservoirs (Meckel 2011; Henry et al. 2017). Furthermore, heterogeneous buried landslides can compromise seal integrity and rearrange subsurface fluid plumbing systems (Gamboa et al. 2011; Riboulot et al. 2013; Maia et al. 2015). The extent of submarine landslide deposits informs the placement of international economic boundaries, as defined by the United Nations Convention on Law of the Sea (e.g. Mosher et al. 2016). The top surfaces of mass failure deposits and areas of evacuation scarring that result from subaqueous landslides are increasingly being recognized as important habitats for seafloor biological communities (Okey 1997; De Mol et al. 2007; Paull et al. 2010; Chaytor et al. 2016a; Huvenne et al. 2016; Savini et al. 2016). The direct impacts of subaqueous landslide activity may also disturb and modify seafloor ecology, and have been suggested as a mechanism for the dispersal of species between isolated islands, thus governing their local evolution (CaujapéCastells et al. 2017). Subaqueous landslides are therefore relevant to a large number of disciplines, governments and industries, as clearly underlined in numerous papers in the predecessor volumes to this special publication (Solheim 2006; Lykousis et al. 2007; Mosher et al. 2010a; Yamada et al. 2012; Krastel et al. 2014; Lamarche et al. 2016).

\section{Value of a global consistent database of subaqueous landslides}

Despite their importance, the study of subaqueous landslides is challenging due to their hard-to-reach nature: often in deep water and far from shore. Step-increases in knowledge have been achieved over the past few decades, however. These are largely as a result of improvements in offshore surveying technologies (enhanced coverage, resolution and accuracy: Hughes Clarke 2018; Mountjoy \& Micallef 2018), coupled with increased offshore resource exploration activities (Thomas et al. 2010), and recognition of the need to quantify the risk posed by subaqueous landslide hazards (Vanneste et al. 2014; Moore et al. 2018). Some of the major national and international programmes that catalysed this knowledge growth include GLORIA and STRATAFORM (offshore USA), Seabed Slope Process in Deep Water Continental Margin (northwest Gulf of Mexico), STEAM and ENAM II (European Atlantic Margins), and COSTA (Mediterranean and NE
Atlantic) (Nittrouer 1999; Locat \& Lee 2002; Canals et al. 2004; Mienert 2004).

The IGCP-585, IGCP-511 and IGCP-640 projects helped to build an international community of subaqueous landslide researchers with diverse technical backgrounds who have documented a large number of subaqueous landslide studies from a range of physiographical, tectonic and sedimentary settings (see papers in Lykousis et al. 2007; Mosher et al. 2010a; Yamada et al. 2012; Krastel et al. 2014; Lamarche et al. 2016). This community of scientists recognizes the need for the compilation of a global subaqueous landslide database, to effectively integrate the wider community knowledge and tackle outstanding scientific questions. This is with a view to support the following activities:

- Provide the basis for statistical analysis to robustly test hypotheses that are currently either only qualitatively addressed or supported by databases with relatively small sample sizes, such as exploring potential links between landslide frequency and sea level/climate change (Geist \& Parsons 2006, 2010; ten Brink et al. 2006; Clare et al. 2016b).

- Identify and quantify the physical controls on landslide frequency-magnitude and triggering between different margin types, and in different settings (e.g. high to low sedimentation regimes, lakes compared to deep-sea, etc.).

- Enable knowledge-gap analysis and to inform future strategies for a more complete data collection (e.g. identify potential blind spots, reconcile geographical, temporal and physiographical biases in the available data, and inform future selection of appropriate sampling and survey techniques).

- Quantitatively compare landslide parameters across a range of scales (from experimental laboratory models, lacustrine and fjord slope failures, to prodigious continental slope collapses) to determine if any scaling relationships exist. For example, can we make informed inferences or extrapolations about the largest events on Earth from easier-to-access examples in lakes or fjords? Can we assess spatial extent through the examination of a failure deposit width or thickness (e.g. Moscardelli \& Wood 2016)?

\section{Existing subaqueous landslide databases}

A number of subaqueous landslide databases already exist, but the manner in which parameters are measured, and hence the consistency between studies, varies between the discipline of the data-gatherer (e.g. lacustrine or marine, ancient or recent stratigraphy) and the end-user focus (e.g. tsunami modelling, seafloor hazard assessment, hydrocarbon exploration, benthic habitat mapping). Existing databases encompass: (i) the submarine landslide frequency (which is generally biased towards events in the 


\section{CLARE ET AL.}

last 40 kyr; Owen et al. 2007; Urlaub et al. 2013, 2014; Brothers et al. 2013; Clare et al. 2014; Hunt et al. 2014); (ii) geotechnical properties (Day-Stirrat et al. 2013; Sawyer \& DeVore 2015); (iii) damage to seafloor infrastructure (Pope et al. 2016, 2017); and (iv) morphometrics (i.e. measurements that record the geospatial dimensions of a landslide: e.g. Moscardelli \& Wood 2016). The latter is the most commonly recorded information as morphometrics are relevant to a wide range of applications, including seafloor geohazard assessments (runout distance, magnitude, spatial frequency), tsunami modelling (failure volumes and directionality), hydrocarbon exploration (extent of evacuation $\mathrm{v}$. depositional zones) and benthic ecology (nature of scar and distribution of deposits). Morphometrics have been compiled for deep-sea landslides in the Mediterranean Sea (Urgeles \& Camerlenghi 2013; Dabson et al. 2016), the North Atlantic Ocean (McAdoo et al. 2000; Hühnerbach \& Masson 2004; Chaytor et al. 2009; Twichell et al. 2009) and the Caribbean (ten Brink et al. 2006; Harders et al. 2011). Compilations also exist for landslides in Alpine, Chilean and Alaskan lakes (e.g. Moernaut \& De Batist 2011; Strasser et al. 2013; Van Daele et al. 2015; Kremer et al. 2017; Moernaut et al. 2017; Praet et al. 2017). The few global compendia of morphometrics that exist (e.g. lakes - Moernaut \& De Batist 2011; deep-seas - ten Brink et al. 2009, 2016; largely based on outcrop and seismic data Moscardelli \& Wood 2016) had very different approaches in how the metrics were measured. So, while these databases are useful for intra-regional or intra-discipline comparisons, the lack of consistency in what is measured, and how, hinders direct comparisons between different studies and thus inhibits the broader, global understanding of subaqueous landslides.

\section{Aims}

An IGCP-640-funded workshop held in January 2017 set out to discuss improved integration between the disciplines for which subaqueous landslides have relevance, and to propose a uniform method for their measurement. A proposed long-term goal is the construction of a global comparative landslide database that will include morphometrics, as well as other parameters. Disciplines represented at the workshop included specialists in lacustrine and deep-water sedimentology, seafloor habitat mapping and ecology, marine geophysics, marine geochemistry, hydrocarbon exploration and production, subsurface fluid flow and storage, offshore and coastal geohazards, and volcanology.

In this paper we tackle three overarching questions. First, what is the benefit of a global database of subaqueous landslides? We discuss how such a database can provide valuable and consistent data for scientific hypothesis testing (e.g. global to local scaling relationships), societally-relevant applications (e.g. hazard assessments), to determine systematic biases and identify data gaps that require filling.

Secondly, we ask what are the challenges and potential pitfalls in making morphometric measurements of subaqueous landslides using different data types, in different basins and in different ages of deposits having undergone different diagenetic changes? A global database should incorporate observations from the modern seafloor and lakes using hull-mounted and higher-resolution (e.g. autonomous underwater vehicle (AUV)) bathymetry, 2D and 3D seismic reflection data imaging both the seafloor and subsurface strata, and outcrop observations. But what are the implications of comparing measurements between these different data types? We aim to understand what can be reliably understood and interpreted from comparisons between morphometric studies.

Finally, we ask how do you measure and describe the morphometry of both modern and ancient subaqueous landslides in a consistent manner? No common method currently exists for the subaqueous landslide community. Here we present, and test, a method that can be widely adopted to enable consistent comparisons between workers, and thus assist in the development of a consistent ancient and modern global database. We identify a number of morphometric parameters to describe a subaqueous landslide and assess the repeatability of measurements made by different operators for the same landslide (Table 1).

\section{How can a global database identify and address systematic biases and knowledge gaps?}

We recognize that there are often a number of systematic biases in studies of subaqueous landslides. We now discuss why these biases exist and how a global database can be used to identify and address those biases, to ensure that future studies can be focused to fill outstanding data and knowledge gaps.

\section{Scale bias}

Many scientific studies have focused on large-scale landslides as they are easier to image in detail than small landslides that are close to the resolution limits of the imaging tools. These larger events are also often considered (e.g. Calves et al. 2015) to pose a greater danger to public safety (e.g. higher tsunamigenic potential) and are therefore the focus of attention. Furthermore, smaller landslides $\left(\ll 1 \mathrm{~km}^{3}\right)$ may be imaged in some surveys, but are often not the foci of follow-up study as they may be less significant for 
MORPHOMETRICS OF SUBAQUEOUS LANDSLIDES

Table 1. Metrics and metadata to be included within a global subaqueous landslide database

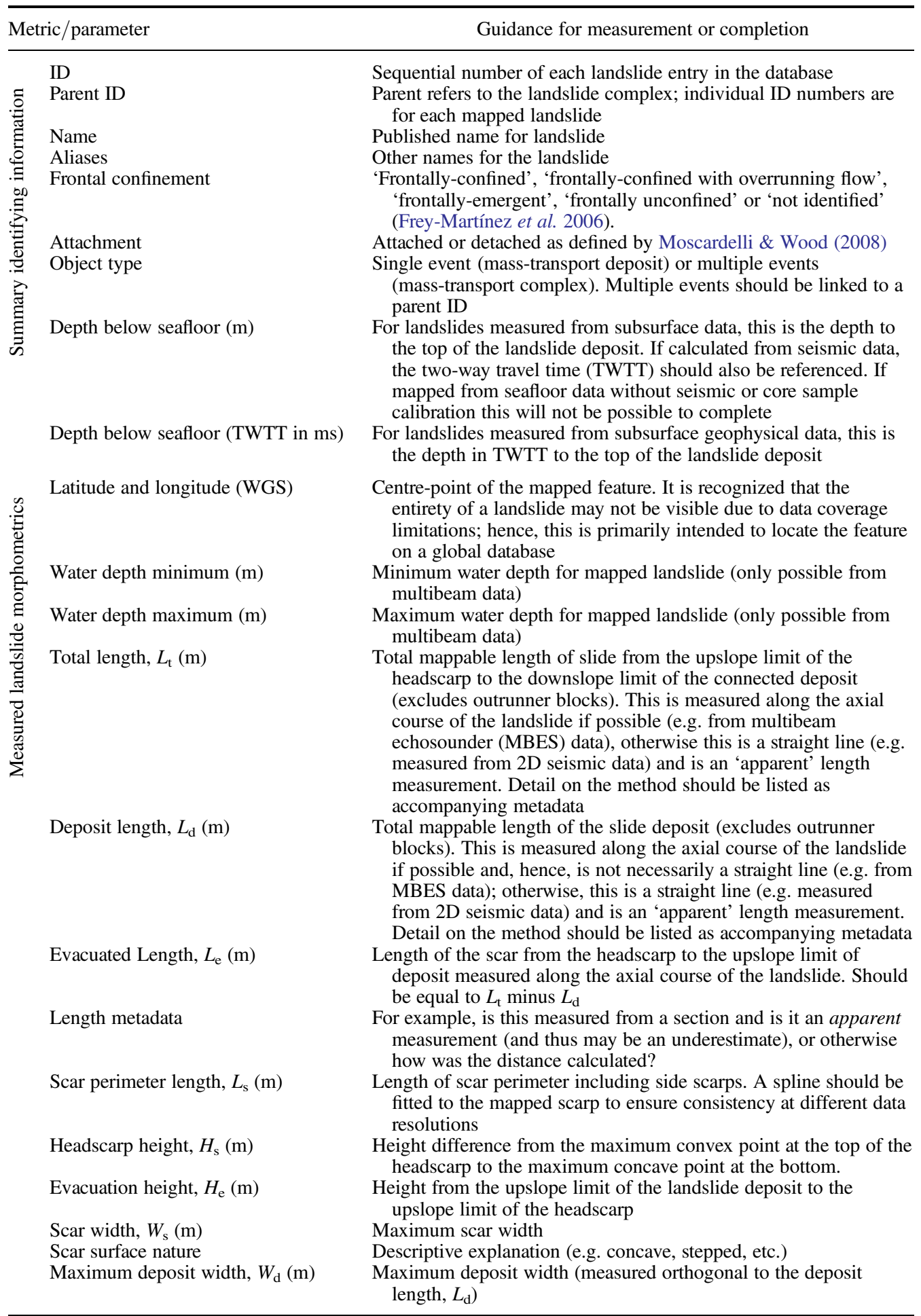




\section{CLARE ET AL.}

Table 1. Metrics and metadata to be included within a global subaqueous landslide database (Continued)

\begin{tabular}{l} 
Metric/parameter \\
\hline Maximum deposit thickness, \\
$T_{\mathrm{d} \max }(\mathrm{m})$ \\
\\
Maximum deposit thickness, \\
$T_{\mathrm{d} \text { max }}(\mathrm{TWTT}$ in ms) \\
Maximum unconfined deposit \\
thickness, $T_{\mathrm{u} \text { max }}(\mathrm{m})$ \\
Maximum unconfined deposit \\
thickness, $T_{\mathrm{u} \text { max }}(\mathrm{TWTT}$ in ms) \\
Thickness metadata
\end{tabular}

Total height drop, $H_{\mathrm{t}}(\mathrm{m})$

Slope gradient, $S\left(^{\circ}\right)$

Slope gradient metadata

Slope gradient of the headscarp, $S_{\mathrm{s}}\left({ }^{\circ}\right)$

Slope gradient of the headscarp metadata

Slope gradient at the toe, $S_{\mathrm{t}}\left(^{\circ}\right)$

Slope gradient at the toe metadata

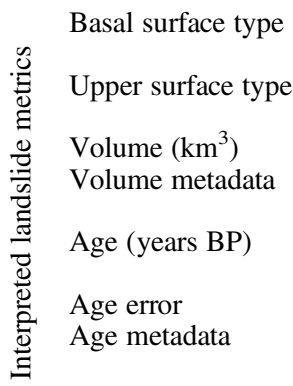

Seafloor features metadata

Data type

Data type metadata

Data source

Data repositories
Guidance for measurement or completion

Maximum measured deposit thickness in metres. Detail should be provided in the accompanying metadata as to how this was measured (e.g. from height on bathymetry or from seismic data) (and where)

Maximum measured deposit thickness in TWTT

Maximum measured unconfined deposit thickness

Maximum measured unconfined deposit thickness in TWTT

How was the thickness calculated? For example, derived from multibeam data, measured from seismic (with which assumed seismic velocity?) or calibrated with core sampling data?

Height from the downslope limit of the landslide deposit and the upslope limit of headscarp

Measured laterally away from the scar outside of the zone of deformation. This is intended to give an estimate of the gradient of the unfailed slope

Notes added here to indicate the distance of the lateral offset of the measurement, distance over which the gradient was measured and any uncertainties, etc.

Maximum slope of the headscarp

Notes added here to indicate where this was measured, the distance over which the gradient was measured and any uncertainties, etc.

Measured in front of the toe outside of the zone of deformation.

Notes added here to indicate the distance of the lateral offset of the measurement, the distance over which the gradient was measured and any uncertainties, etc.

Description of the basal surface, if mappable (e.g. rugose, planar, etc.)

Description of the upper surface, if mappable (e.g. rugose, smooth, etc.)

Calculated deposit volume

How was the volume calculated? What are the assumptions? Which published method was used (if any?)

If known, this is the age of the landslide in years. This may be an absolute value or a constrained age (e.g. $>45 \mathrm{ka})$

Where available, the error ranges of the dates should be presented

Information on the dating method, uncertainties, where the sample was taken (location and depth relative to the landslide deposit) and any assumptions should be referenced. Here the source of the age should also be referenced

Useful additional information about seafloor features in the vicinity or in association with the landslide deposit, such as evidence of fluid expulsion (e.g. pockmarks)

Data on which the mapping was based. High-level statement (e.g. bathymetry, combined bathymetry and geophysics, core, deep seismic).

Data on which the mapping was based - more details can be provided here on combinations of sources (e.g. hull-mounted multibeam data, AUV data, 2D/3D seismic, sediment cores, etc.). This may be a combination of sources

Reference to where the data came from (e.g. the data provider and the cruise, etc.). This should, ideally, include a hyperlink(s)

Where can the raw/processed data be found if they are available? This should include a hyperlink if available 
Table 1. Metrics and metadata to be included within a global subaqueous landslide database (Continued)

\begin{tabular}{|c|c|}
\hline Metric/parameter & Guidance for measurement or completion \\
\hline Publication source & $\begin{array}{l}\text { Where is the peer-reviewed source? If there is not one, then link to } \\
\text { a cruise report or equivalent. If not published, then this needs to } \\
\text { be flagged. This should include a hyperlink }\end{array}$ \\
\hline Depth below seafloor metadata & $\begin{array}{l}\text { Notes to accompany the depth. For instance, is it the only } \\
\text { measureable depth, an average depth or maximum depth? What } \\
\text { was the assumed (or calibrated) seismic velocity? }\end{array}$ \\
\hline Data contact & Who is the contact for this dataset? \\
\hline Database entry attribution & Who entered the data in the database? \\
\hline Database entry notes & $\begin{array}{l}\text { Any specifics to the data that were entered. For example, was the } \\
\text { length recalculated from that in the original published material? }\end{array}$ \\
\hline Data horizontal resolution & $\begin{array}{l}\text { What is the horizontal resolution of the data from which the } \\
\text { measurements were made? }\end{array}$ \\
\hline Data vertical resolution & $\begin{array}{l}\text { What is the vertical resolution of the data from which the } \\
\text { measurements were made? }\end{array}$ \\
\hline Additional notes & $\begin{array}{l}\text { Comments on any other information/considerations that should be } \\
\text { borne in mind when using these data }\end{array}$ \\
\hline
\end{tabular}

In the online database entry form (https://goo.gl/o69UvY), a metadata field accompanies each of the measured metrics to record free text commentary concerning uncertainties, errors and operator decision making.

sediment transport or petroleum systems. Thus, there is often a tendency in scientific literature towards the landslides on the largest end of the scale (e.g. Masson 1996); however, even small landslides can pose a hazard to seafloor infrastructure (Forsberg et al. 2016; Clare et al. 2017) and their combined influence on net sediment transport may be as significant as an individual large landslide (Casas et al. 2016). Future efforts should be made to integrate measurements of smaller landslides and several recent studies have attempted to make this integration (e.g. Baeten et al. 2013; Casas et al. 2016; Madhusudhan et al. 2017).

\section{Preservational bias}

We often make measurements based on surfaces preserved at seafloor or the lakebed, from seismic data or in outcrops; however, recent repeated surveys have shown that a dramatic reworking of landslide scars and deposits can occur very soon after deposition in some settings. For instance, the volume of a submarine landslide deposit in the head of Monterey Canyon, California was reduced by $80 \%$, while the scar area increased by $40 \%$, over the course of less than 2 years due to current reworking (Smith et al. 2007). The evidence of landslide morphology can be entirely wiped out in weeks to years in regions with high sedimentation rates, such as submarine deltas (e.g. Biscara et al. 2012; Hughes Clarke et al. 2014; Clare et al. 2016a; Kelner et al. 2016; Obelcz et al. 2017). Thus, one must acknowledge that studies of subaqueous landslide deposits record only the preserved history and may not be a full representation of all past events. The increasing use of repeat surveys (Hughes Clarke 2018) and direct monitoring of submarine landslides (Clare et al. 2017; Urlaub et al. 2018) provide valuable resources from which to understand the limitations of analysing the resultant features on the seafloor, in seismic reflection data and from outcrop ancient deposits.

\section{Temporal bias}

There is currently a strong bias in published databases and collations of subaqueous landslides to those that are less than $c .40$ kyr old (i.e. the limits of radiocarbon dating: Brothers et al. 2013; Urlaub et al. 2014). Current sampling and dating methods limit the age controls we have on more ancient failure deposits. This temporal bias provides challenges when testing hypotheses such as the influence of sea level on failure frequency or linkages between climate and failure, as the spread of landslide occurrence does not span sufficient sea-level stands or climatic intervals (Pope et al. 2015). Future databases should integrate modern seafloor studies with studies of older landslides, which can be dated using other multiproxy methods (e.g. oxygen isotopes, coccolithophore biostratigraphy, magnetostratigraphy and tephrochronology: Hunt et al. 2014; Clare et al. 2015; Coussens et al. 2016) and imaged at depth using seismic data (e.g. Gamboa \& Alves 2016).

\section{Geographical and economic bias}

Until recent years, compilations of submarine landslide morphometrics largely focused on the $\mathrm{NE}$ Atlantic, North American, Iberian and Mediterranean continental margins (Pope et al. 2015), where higher-resolution data were collected due to offshore 


\section{CLARE ET AL.}

exploration and scientific focus (e.g. Micallef et al. 2007). However, high-resolution data are now being collected in other areas, such as South America (Völker et al. 2012) and Australasia (Clarke et al. 2012; Micallef et al. 2012). A number of regions are noticeably under-represented in subaqueous landslide compilations, however; particularly those where data is scarce (e.g. East Africa) and around developing countries that are highly sensitive to tsunami impact (e.g. South China Sea - Hu et al. 2009; He et al. 2014; Terry et al. 2017; South Pacific - Goff \& Terry 2016). A truly global database will enable a more robust understanding of where data are required to better understand which regions are more and less prone to landslides (and of what type/scale, etc.). Future research efforts should be focused on such regions to develop appropriate risk-management procedures for developing countries, and provide a more globally-balanced view of subaqueous landslides. Information from a global database could, however, be used to evaluate the potential for landslide occurrence along data-limited margins where conditions are analogous to other better-studied margins (Adams \& Schlager 2000; Piper \& Normark 2009). A consistent global database can provide the basis for some initial likelihood estimates in the absence of margin-specific data, thus extending the use of available studies to vulnerable communities.

\section{What are the challenges and potential pitfalls for the morphometric characterization of subaqueous landslides?}

We now outline the main issues encountered when attempting to measure the morphometry of subaqueous landslides.

\section{Low data resolution relative to landslide scale}

The accuracy of any morphometric landslide measurement is a function of the resolution of the data relative to the scale of the landslide (Fig. 1). In many cases, it may be possible to make reliable measurements of first-order morphometrics, such as total landslide length or scar width, using relatively coarse resolution (often hull-mounted) multibeam data (e.g. in Fig. 2b, a similar landslide outline could be mapped from $30 \mathrm{~m}$ binned data compared to that from $0.5 \mathrm{~m}$ bin size). However, it is still possible that many small landslides will be missed using such coarse-resolution data and more detailed measurements of evacuation or deposit length are often not feasible. It is unlikely that accurate measurements would be made of the landslides shown in Figure 2a or d using the $30 \mathrm{~m}$ bin size data alone. We must recognize, therefore, that landslide catalogues and databases are incomplete (Malamud et al. 2004; Urgeles \& Camerlenghi 2013). Measurement of landslides from older legacy data, that are often very low resolution, is particularly prone to this problem. The growing trend for using autonomous underwater vehicles (AUVs: Wynn et al. 2014) and remotely operated vehicles (ROVs: Huvenne et al. 2016, 2018) to map the seafloor will enable us to tackle this issue and start populating the missing lower end of the scale. This is comparable to that encountered when mapping other seafloor features, such as bedforms, where new highresolution AUV data have enabled an update of a pre-existing classification system (Wynn \& Stow 2002) to fill in some of the blanks (Symons et al. 2016).

Length measurements of irregular features, such as scar perimeter, are often highly variable between operators, depending on how complex the feature is deemed to be by each individual and to what level of detail they define it. Limited time availability for measurement, coupled with a large number of landslides, can lead to reduced detail in mapping and, thus, resulting in smaller perimeter lengths compared to a more detailed analysis. Furthermore, the measured length of a complex feature will increase if data resolution is enhanced, due to the improved imaging of a greater morphological complexity. This issue is comparable to the coastline paradox of Mandelbrot (1967), wherein the coastline of Britain apparently lengthens as the resolution of measurement becomes finer.

\section{Large landslide scales relative to the survey area}

It is difficult to accurately define landslides whose extents are at the limits of the data resolution (Gamboa \& Alves 2016). However, it is also clear through examining the distribution of landslide deposit sizes that there are many events that extend beyond the spatial limits of a survey or the lateral extent of outcropping strata (Moscardelli \& Wood 2016). This latter issue is well illustrated by prodigiousscale landslides, such as the Sahara Slide (offshore NW Africa: Georgiopoulou et al. 2010), that are so large it is usually impractical to survey their full areal extent (Fig. 3e) (Li et al. 2017). Similarly, the full extent of landslides is often not imaged in seismic datasets where features are cropped at the limits of the survey area or whose thickness is close to the vertical resolution limits of the data (Alves \& Cartwright 2009; Moscardelli \& Wood 2016). In such scenarios, it is possible to make measurements of the partial scar or deposits, recognizing that measurements are likely to be underestimated. Where such measurements are recorded in a database, the limitations of the available data coverage relative to the 
MORPHOMETRICS OF SUBAQUEOUS LANDSLIDES

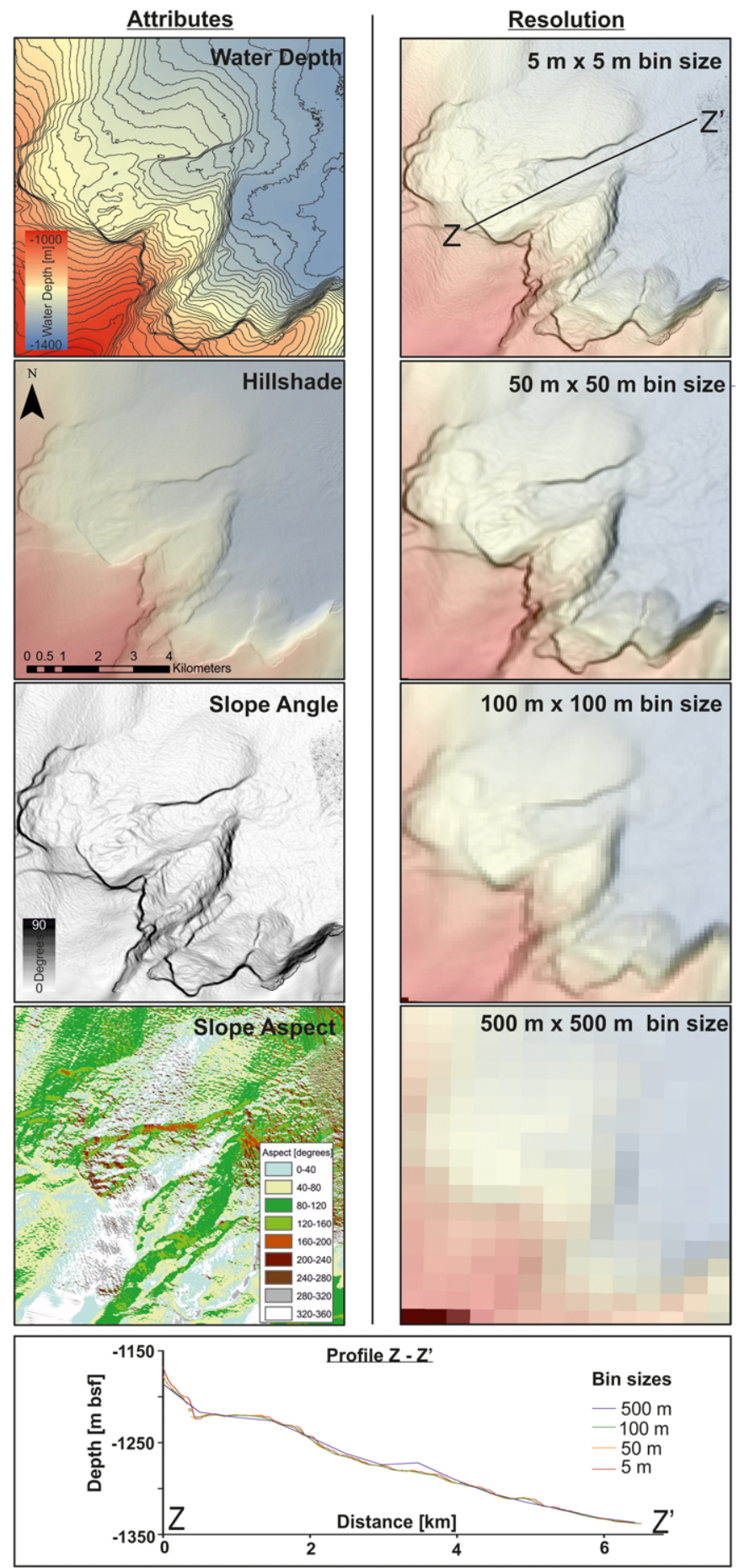

Fig. 1. (Left) Examples of attribute analysis applied to bathymetric datasets to assist in the measurements of landslide morphometrics. Example shown is from the southern Tyrrhenian Sea based on $0.5 \times 0.5 \mathrm{~m}$ bin size AUV bathymetry. (Right and lowermost panel) Progressive downsampling of the same AUV bathymetry to demonstrate the implications of data resolution for imaging landslides from seafloor data. 

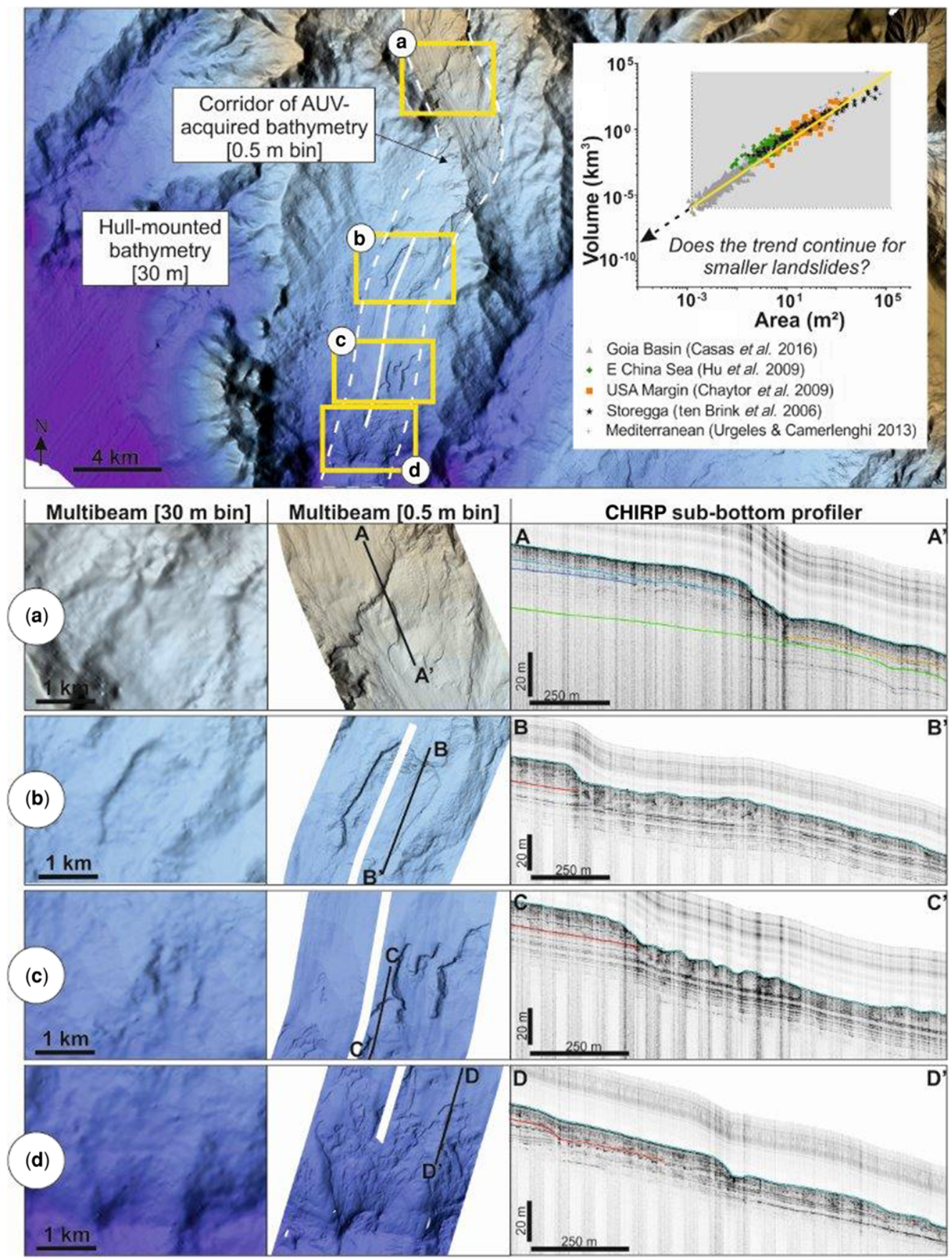

Fig. 2. Example bathymetry from the Western Mediterranean illustrating how many small landslides observed in AUV bathymetry $(0.5 \mathrm{~m}$ bin size $)$ cannot be clearly imaged from hull-mounted bathymetry $(c .30 \mathrm{~m}$ bin size $)$. Inset graph shows published morphometric data (area versus volume), highlighting the absence of smaller landslides. Representative AUV CHIRP profiles are presented in the lower panels a-d to illustrate the nature of the sub-bottom acoustic character for several of the small landslides. 


\section{MORPHOMETRICS OF SUBAQUEOUS LANDSLIDES}
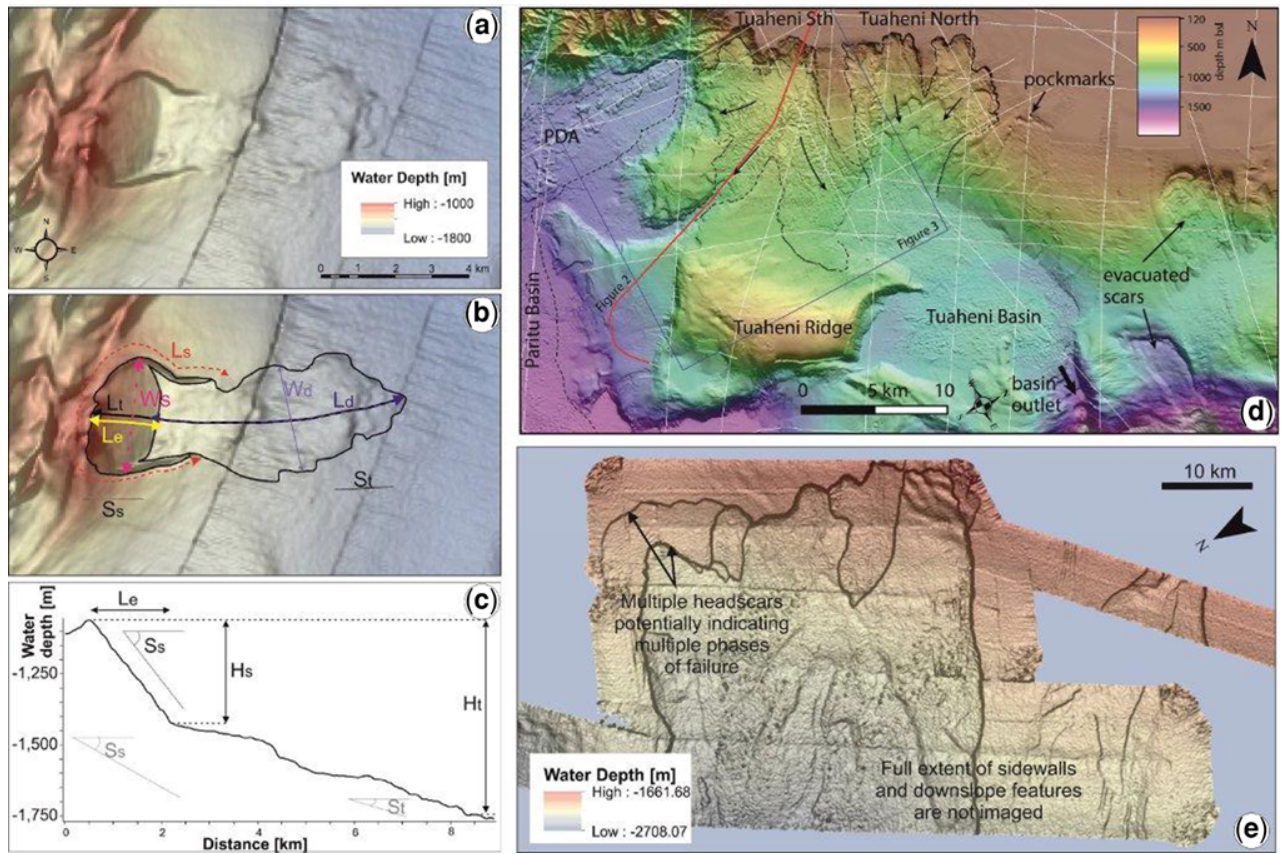

(c)

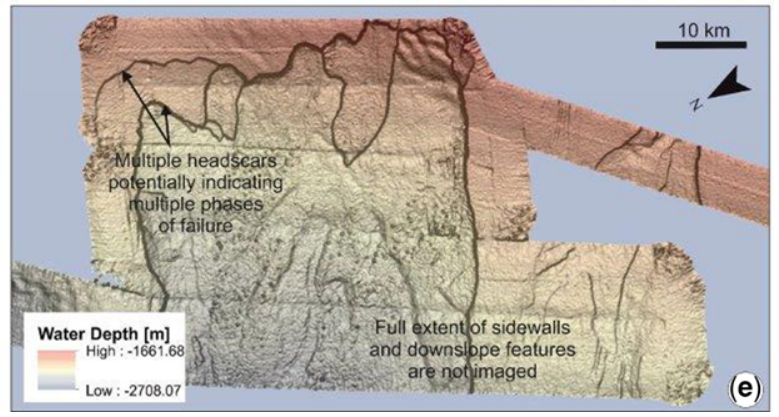

Fig. 3. Subaqueous landslide case studies discussed in this contribution (a) Colourscale bathymetry overlain on a greyscale slope map for relatively simple landslide (the Valdes Slide: Völker et al. 2012) offshore Chile. Example of the measured parameters for this study for the Valdes Slide are based on the plan view (b). (b) \& (c) Measurements from a representative slope profile. (d) More complicated landslide example (Tuaheni Slide, New Zealand; modified from Mountjoy et al. 2014). Note the cross-cutting relationship of the South and North Tuaheni slide components. (e) Example of a large submarine landslide (Sahara Slide; Li et al. 2017), where only part of the scar is imaged.

scale of the landslide should be acknowledged in accompanying metadata and must be considered in comparative analysis.

\section{Differentiating evacuation from depositional zones}

Assuming data are resolute enough and the entire landslide is imaged, the measurement of landslide length should be straightforward as it is defined by the major morphological features of a landslide (i.e. the distance from headscarp to toe: Fig. 4). Thus, to a first order, the scale of a landslide should be consistently recorded between operators. Inconsistencies may arise, however, when attempting to demarcate where an evacuation zone ends and the deposit begins, as a higher degree of interpretation is required. Some of this subjectivity can be removed where observations based on multibeam data can be calibrated with seismic data (e.g. Figs 2 and 5). Changes in acoustic character and breaks in the continuity of seismic reflections provide valuable information on defining limits of intact stratigraphy, zones of removed sediment and disruption of transported sediment (e.g. Alves \& Cartwright 2009;
Alves et al. 2014; Strupler et al. 2017). While this enables better demarcation of evacuation and depositional zones, any measurement of length that is based solely on coarsely-spaced 2D seismic data (or 2D outcrops for that matter) will be an 'apparent' measurement, and is thus likely to be an underestimate. Seismic lines are rarely acquired perfectly along the axis of runout (e.g. Fig. 2). Moscardelli \& Wood (2016) recognized this shortcoming in their morphometric analysis of landslides and took a simplistic approach to measure length (straight line distance measured from headscarp to downslope limit of deposit). Thus, any comparison of measurements based on coarsely-spaced 2D seismic with those made from multibeam or 3D seismic data results in an estimate that may be misleading unless the line spacing is close enough. For this reason, it is preferable that measurements are integrated where complementary multibeam and seismic datasets are available.

\section{How and where to measure slope gradient}

The measurement of slope gradient is important given the sensitivity of slope stability analysis and 
M. CLARE ET $A L$.

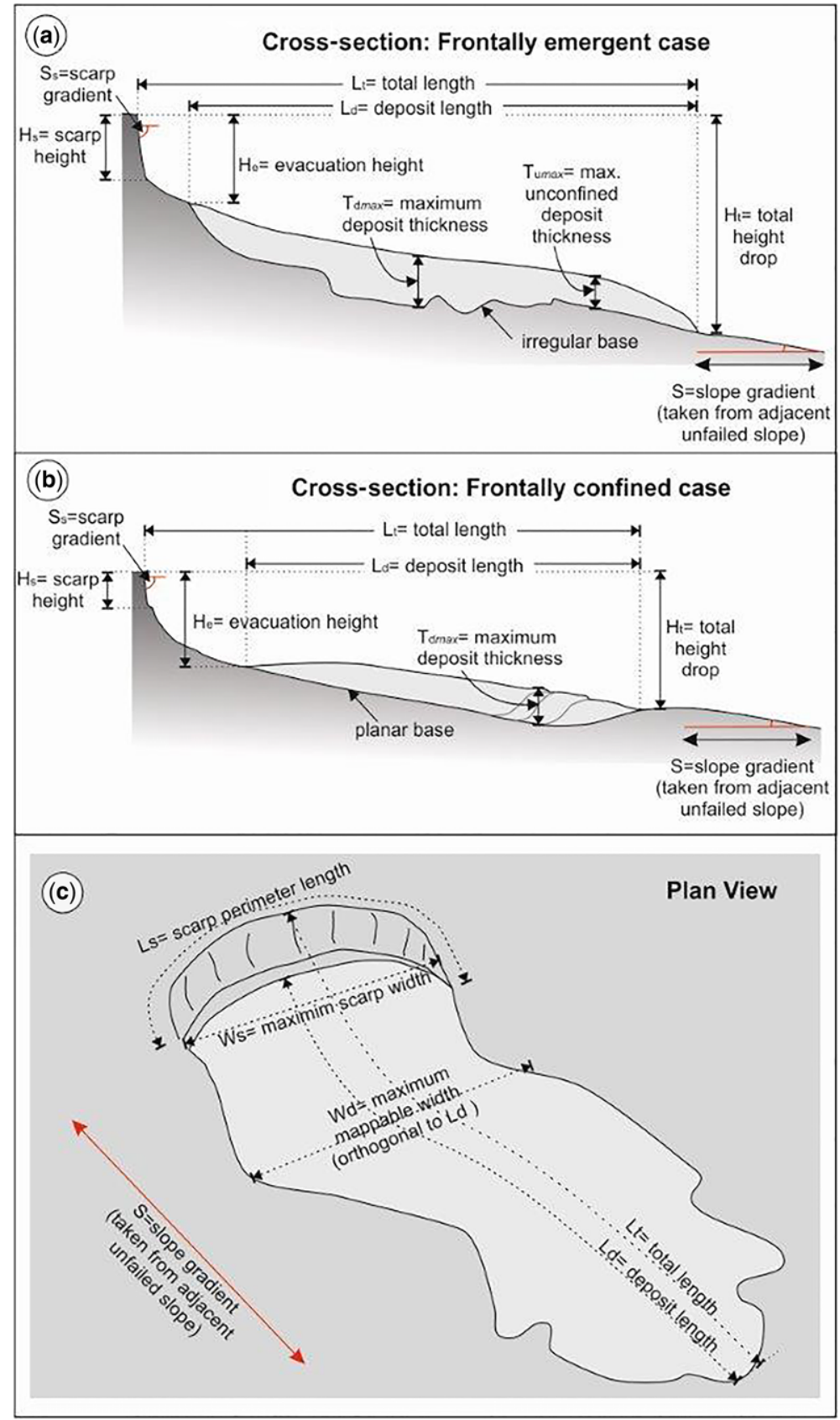

Fig. 4. Schematic illustration of morphometric parameters defined in Table 1 showing (a) frontally-emergent and (b) frontally-confined landslide cases in cross-section, and (c) a plan view of the landslide.

volume calculations to slope gradients. This is also crucial for seismic-based studies of buried landslides, as the velocities considered for distinct overburden intervals will affect the measured slope angles. The location and the distance over which measurements of slope gradient are made will greatly influence the result. Thus, it is important that the location and length over which slope gradient is measured are well documented, otherwise comparisons between studies may be meaningless. 


\section{MORPHOMETRICS OF SUBAQUEOUS LANDSLIDES}
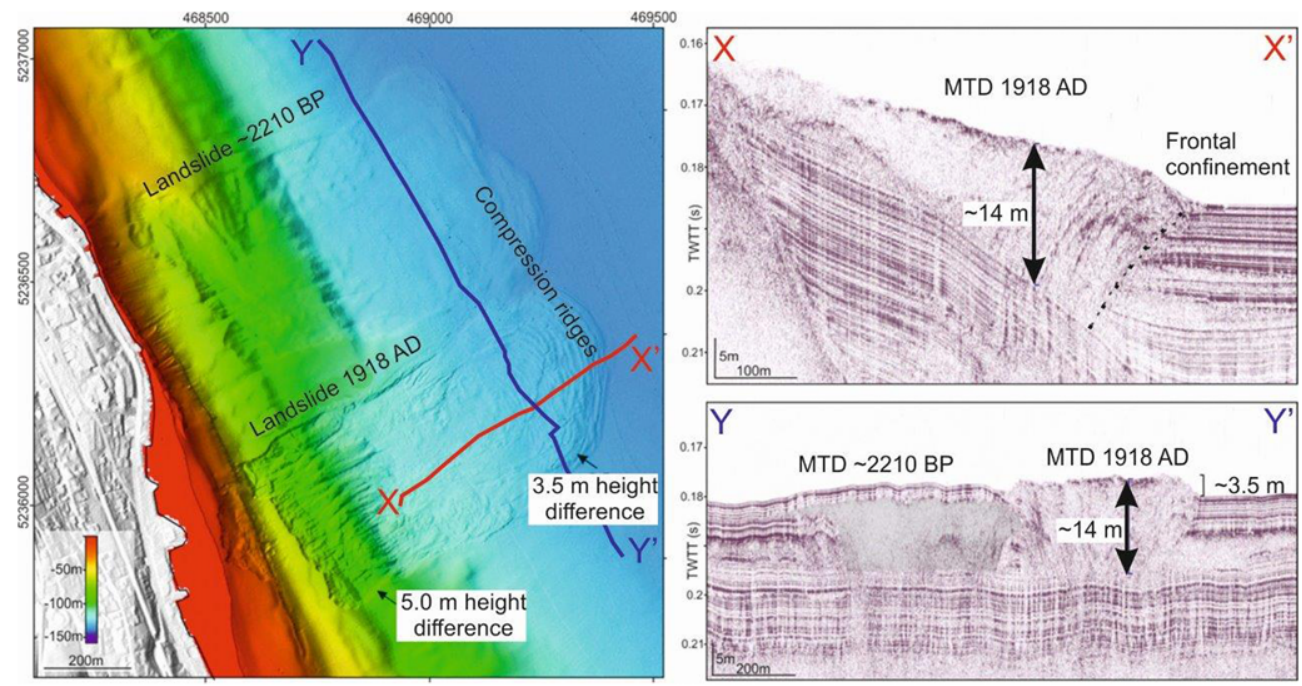

Fig. 5. Example of frontally-confined landslides in Lake Zurich (modified from Strupler et al. 2017). Volumes based on thickness measurements from multibeam data are a factor of 3 less than those calculated from seismic data.

\section{Competing subaqueous landslide classification schemes}

A large number of classification schemes exist for terrestrial and subaqueous landslides (e.g. Varnes 1958; Hampton et al. 1996; Mulder \& Cochonat 1996; Locat \& Lee 2002; Masson et al. 2006; Moscardelli \& Wood 2008; Hungr et al. 2014). There is a high degree of subjectivity in the interpretation of failure mode or the nature of displacement, however. Furthermore, the complex and often transformative rheology of subaqueous mass movements along their course (e.g. Talling et al. 2007; Haughton et al. 2009; Richardson et al. 2011) makes a genetic classification challenging. On a more simple level, however, subaqueous landslides can be differentiated by: (i) the nature of the landslide front (i.e. the degree of frontal confinement); and (ii) the relationship of the landslide to its source area (i.e. attached or detached).

It is important to discriminate between landslides with different degrees of frontal confinement, as these are associated with different formative mechanisms, downslope propagation, internal kinematics and resultant deposits (Frey-Martínez et al. 2006). Frontal confinement is classified by Frey-Martínez et al. (2006) as either: (a) 'frontally-confined' landslides, where the landslide front abuts undisturbed sediments; or (b) 'frontally-emergent' landslides that ramp up from their original stratigraphic position to move across the lake or seafloor unconfined (Moernaut \& De Batist 2011). Such a simple binary classification does not take into account natural complexity and only applies to translational failures which start on an intact slope profile; hence, we suggest that the following terms are also used: (c) 'frontally-confined with overrunning flow', where a debris flow or incipient failure may runout over the confined toe of a landslide; (d) 'frontally-unconfined' landslides, where there is no downslope buttressing, such as where the toe of a slope has been excavated by erosion or in the case of rotational failures (Lacoste et al. 2012); and (e) 'not identified', where the data do not enable the classification to be made.

Moscardelli \& Wood (2008) proposed a binary classification for landslide attachment that includes: (a) landslide deposits which are attached to their source area, which are typically regionally extensive features that occupy hundreds to thousands of square kilometres in area; and (b) landslide deposits that are detached from their scar, which are typically much smaller. Whether or not landslides are attached to their scar reveals information about the nature of the failure, if landslides were potentially tsunamigenic and has been suggested to provide an indication of a potential triggering mechanism (Moscardelli \& Wood 2008). The use of both approaches ensures that at least one classification can be made even if only the source, or the front (terminal end), of a landslide is imaged and avoids the high degree of subjectivity in other more complicated genetic classification schemes.

\section{Challenges in calculating landslide volumes}

Numerous methods have been applied to the calculation of landslide volume from multibeam bathymetry data. The first is based on an estimation of the 


\section{CLARE ET AL.}

missing volume from a scar: calculated from the difference between the scar topography and an interpolated surface that connects the upper edges of the scar. This approach thus aims to reconstruct the prefailure topography (ten Brink et al. 2006; Chaytor et al. 2009; Katz et al. 2015; Chaytor et al. 2016a, $b)$. The second method is based on the measured scar dimensions (McAdoo et al. 2000), wherein the landslide volume is modelled as a wedge geometry (volume $=1 / 2 \times$ area $\times$ height). The lower plane of the wedge is derived from slope angles of the runout and/or scar, and the upper plane is based on the gradient of the unfailed slope immediately adjacent to the seafloor (assumed to be representative of the pre-failure slope). The third method is based on the measurements of the landslide deposit itself. This approach is often used when the scar is not preserved or surveyed (e.g. Masson et al. 2006; Alves \& Cartwright 2009). In such a scenario, volume is determined as a function of landslide thickness and area (in the case of the lower measured value, this was estimated as volume $=$ area $\times 2 / 3$ maximum deposit thickness).

Ideally, additional data should supplement the calculation of landslide volume to calibrate the accuracy of measurements based on multibeam data alone. In Figure 5, we illustrate the value of complementary seismic data to calculate volumes of a frontally-confined lacustrine landslide in Lake Zurich (Strupler et al. 2017). First, we calculated volumes based on the multibeam bathymetry. A missing volume of $800000 \mathrm{~m}^{3}$ was derived from the scar height $(5 \mathrm{~m})$ and its areal extent (using the method of ten Brink et al. 2006). This value is comparable to the volume calculated from the deposit area and its height above the adjacent seafloor $(3.5 \mathrm{~m})$ mapped from bathymetry, which was calculated as $740000 \mathrm{~m}^{3}$. High-resolution seismic profiles indicate that the thickness of the landslide $(19 \mathrm{~ms}=$ $14 \mathrm{~m}$ ) is actually much greater than the measured heights from multibeam bathymetry $(3.5-5 \mathrm{~m})$. The calculated volume was revised upwards by a factor of 3 to $2200000 \mathrm{~m}^{3}$. This is a fundamental issue, particularly when dealing with landslides that are buttressed at their downslope limit (i.e. 'frontally confined'), as the sediment does not run over the lakebed or seafloor: hence, its bathymetric expression is limited compared to the total thickness of sediments that are displaced. This underlines the importance of integrating seismic data (Alves \& Cartwright 2009). 3D seismic data can provide more accurate landslide volume calculations if the deposit is fully covered by the survey and adequate time-depth conversions are made. Thus, landslide volume should be calculated based on the integration of multibeam and seismic data, where available. However, if only multibeam data are available, then the preferred volume estimates should be calculated based on scar morphometrics, following the approach of ten Brink et al. (2006).

\section{Modification of landslide morphology under burial}

Modern multibeam bathymetry and high-frequency sub-bottom profiling data enable high-resolution mapping of modern landslides (i.e. those that can be imaged at seafloor); however, additional challenges are faced when measuring older landslides imaged in lower-frequency seismic data, besides just resolution issues. Under burial, lithification and compaction processes can change the original morphology of landslide deposits. Mapping of landslides from seismic data is typically based on changes in the morphology, as well as the seismic character within the landslide that is a function of both lithology and internal deformation (Ogiesoba \& Hammes 2012; Alves et al. 2014). Thus, there must be a recognition that any comparison of recent landslide deposits with those that may have undergone significant post-depositional modification is not necessarily like-for-like. Despite this, there is considerable value in comparing recent landslides with the range of events that have happened over a longer timescale in Earth history. Such a comparison may lead to the development of correction factors to enable more effective integration between modern and ancient studies.

\section{Further complications caused by natural complexity}

Many subaqueous landslides are highly morphologically and structurally complex. Such complexity increases the number of interpretative decisions that must be made by the operator when measuring morphometry. Many landslides do not fail as one single event; instead, occurring in stages over both short and long timescales (e.g. Cassidy et al. 2014: Mastbergen et al. 2016). In such cases, the scar may be highly irregular, stepped or feature smaller incipient failures along the headscarp, complicating the measurement of headscarp height and scar dimensions (e.g. Georgiopoulou et al. 2013; Katz et al. 2015) (Fig. 3e). Areas that are highly prone to landslides may feature aggregated or cross-cutting evacuation scars and deposits from multiple different failure events. For instance, the Traenadjupet Slide overlies and cuts into the older Nyk Slide, offshore Norway (Lindberg et al. 2004). Figure 3d shows the case of the Tuaheni landslide complex, where multiple landslides intersect each other, and may have caused reworking of both deposits and parts of the scar (Mountjoy et al. 2014). 


\section{MORPHOMETRICS OF SUBAQUEOUS LANDSLIDES}

The large-scale Laurentian Fan landslide presented by Normandeau et al. (this volume, in press) is an example of a complex failure that also shows localized variation in its frontal confinement; in places, the front of the failure abuts the stratigraphy, while in others it ramps up and becomes emergent. It is thus difficult to classify into just one category. Landslide fronts can become frontally emergent at several locations, such as the $900 \mathrm{~km}^{3}$ Traenadjupet Slide, offshore Norway (Laberg \& Vorren 2000). In that case, multiple lobes formed at the different emergence points, thus providing several options for measuring total landslide length. The interaction of landslides with the underlying stratigraphy, particularly where erosion, ploughing or stepped frontal ramps occur, can further complicate the measurement of thickness and, in turn, the associated calculation of volume from deposits (e.g. Richardson et al. 2011; Puzrin 2016).

\section{How can the morphometry of subaqueous landslides be measured consistently?}

A standardized approach does not yet exist for consistent morphometric characterization of subaqueous landslides. Here, we present a method for measuring key subaqueous landslide morphometrics that can be applied to seafloor, subsurface and outcrop data in their full range of settings. The morphometric parameters chosen are deemed to be relevant to a broad suite of disciplines. We provide instructions on how to measure each parameter (Table 1; Fig. 4). Given variations in data limitations and extent of study area, it may not be possible to measure all of these parameters in all cases; however, our intention is to provide a comprehensive list to enhance the utility of a global database and to ensure that measurements are made consistent.

\section{Testing a standardized approach}

In order to test our approach for measuring landslide morphometrics, we analysed data from the Valdes Slide, offshore Chile (Fig. 3a) (Völker et al. 2012). A relatively simple case study was chosen for this applications test to first understand the limitations of the method in a close-to-ideal scenario. The Valdes Slide is considered to be a relatively simple landslide as it does not feature multiple lobes, the scar is well imaged and it is of a scale such that most morphometrics can be measured clearly. Each operator's analysis was performed in isolation to try to reduce interpretational bias. Software packages used for the analysis varied between operators, and included ESRI ArcGIS, Global Mapper, Teledyne CARIS, Fledermaus and Open Source QGIS. Operators based their analysis of the bathymetry on a number of different attribute tools, including contour, hillshaded illumination, slope angle and aspect tools (e.g. Fig. 1), as well as 3D visualization. Results from each of the individual operators were then collated and compared to understand the variance in outputs (Table 2; Fig. 6).

Consistency in measurement of first-order parameters. Parameters that locate the Valdes Slide (latitude, longitude and water depth) showed very good

Table 2. Results of morphometric analysis performed by the individual authors for the Valdes Slide (Fig. 3a)

\begin{tabular}{|c|c|c|c|c|c|c|}
\hline Parameter & Mean & $\begin{array}{l}\text { Standard } \\
\text { Deviation }\end{array}$ & Minimum & Maximum & $\begin{array}{l}\text { Range } \\
\text { (actual) }\end{array}$ & $\begin{array}{l}\text { Range }(\% \\
\text { of mean) }\end{array}$ \\
\hline Latitude centre point & -35.5245 & 0.0033 & -35.5321 & -35.5206 & 0.0115 & 0.03 \\
\hline Longitude centre point & -73.3625 & 0.0118 & -73.3820 & -73.3542 & 0.0278 & 0.04 \\
\hline Water depth minimum (m) & 1063 & 16 & 1041 & 1090 & 49 & 4.61 \\
\hline Water depth maximum (m) & 1739 & 15 & 1712 & 1762 & 50 & 2.88 \\
\hline Total length, $L_{\mathrm{t}}(\mathrm{m})$ & 6733 & 325 & 6243 & 7036 & 793 & 11.78 \\
\hline Deposit length, $L_{\mathrm{d}}(\mathrm{m})$ & 5443 & 595 & 4813 & 6750 & 1937 & 35.59 \\
\hline Evacuated length, $L_{\mathrm{e}}(\mathrm{m})$ & 1469 & 182 & 1100 & 1741 & 641 & 43.64 \\
\hline Scar perimeter length, $L_{\mathrm{s}}(\mathrm{m})$ & 7142 & 1455 & 3960 & 8000 & 4040 & 56.57 \\
\hline Scar height, $H_{\mathrm{s}}(\mathrm{m})$ & 366 & 10 & 355 & 385 & 30 & 8.19 \\
\hline Evacuation height, $H_{\mathrm{e}}(\mathrm{m})$ & 359 & 9 & 343 & 370 & 27 & 7.52 \\
\hline Height drop, $H_{\mathrm{t}}(\mathrm{m})$ & 664 & 32 & 617 & 697 & 80 & 12.05 \\
\hline Scar width, $W_{\mathrm{s}}(\mathrm{m})$ & 3121 & 263 & 2581 & 3500 & 919 & 29.44 \\
\hline Maximum deposit width, $W_{\mathrm{d}}(\mathrm{m})$ & 3153 & 471 & 2785 & 4200 & 1415 & 44.88 \\
\hline $\begin{array}{l}\text { Maximum deposit thickness, } \\
T_{\mathrm{d} \max }(\mathrm{m})\end{array}$ & 32 & 9 & 25 & 38 & 13 & 41.27 \\
\hline Slope gradient, $S\left(^{\circ}\right)$ & 7.10 & 1.43 & 5.70 & 10.10 & 4.40 & 62.00 \\
\hline Slope gradient of headscarp, $S_{\mathrm{s}}\left(^{\circ}\right)$ & 13.36 & 1.93 & 10.00 & 16.50 & 6.50 & 48.65 \\
\hline Slope gradient toe, $S_{\mathrm{t}}\left(^{\circ}\right)$ & 2.68 & 0.39 & 2.00 & 3.17 & 1.17 & 43.70 \\
\hline
\end{tabular}




\section{CLARE ET AL.}

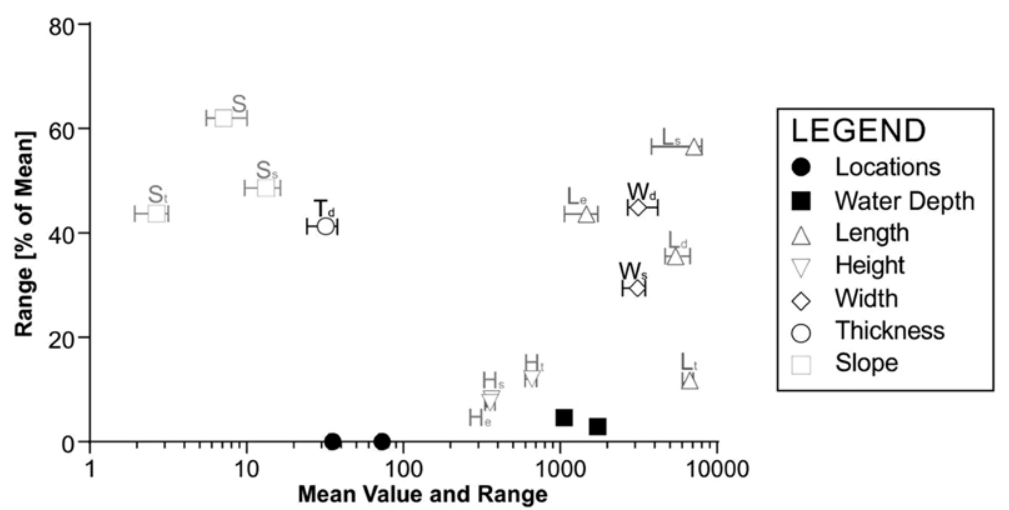

Fig. 6. Mean values (symbols) and total range (whiskers) from a morphometric analysis of the Valdes Slide (Fig. 3a) performed by the authors based on data in Table 2 .

agreement $(<5 \%$ range from the mean measured values (RMMV): Table 2). Measurements of total length measured along the landslide axis $\left(L_{\mathrm{t}}\right)$ and the height drop $\left(H_{\mathrm{z}}\right.$ : defined here as the difference between the minimum and maximum water depth) were comparable between operators (c. $12 \%$ RMMV). The headscarp height $\left(H_{\mathrm{s}}\right)$ and evacuated height $\left(H_{\mathrm{e}}\right)$ also yielded comparable values $(8-12 \%$ RMMV: Table 2). Landslide length (runout), height drop and headscarp height are important first-order parameters in quantifying the scale of a landslide. It is therefore reassuring that the measured values are similar between operators and provide a degree of confidence for comparing other well-defined landslides using these first-order metrics. Thus, a global database should provide useful and comparable measurements of landslide location and scale.

Variance arising from increasing operator decision making. As anticipated, evacuated length $\left(L_{\mathrm{e}}\right)$ and depositional length $\left(L_{\mathrm{d}}\right)$ yielded more disparate results (44 and 36\% RMMV, respectively: Table 2). This is attributed to the fact that the operator needs to make an interpretative judgement based on the analysis of bathymetry data as to where evacuation ends and deposition starts. This subjectivity could be reduced by integrating supplementary datasets such as sub-bottom profiles; however, in situations where further data are not available, it is important that the potential error is made clear in any metadata accompanying these measurements.

Measurements of scar width $\left(W_{\mathrm{s}}\right)$ and deposit width $\left(W_{\mathrm{d}}\right)$ provided RMMV of 29 and $45 \%$, respectively (Table 2). An even wider spread of values (57\% RMMV) was determined for scar perimeter length $\left(L_{\mathrm{S}}\right)$. The variance in these parameters is attributed to the fact that these measurements are based on a higher degree of operator decision mapping, which introduces a large degree of subjectivity to the analysis. We suggest a spline should be fitted to the measured perimeter length to ensure consistency in measurement to account for different levels of data resolution. The least consistently measured parameters were slope angles $\left(S, S_{\mathrm{s}}, S_{\mathrm{t}}\right.$ : 44-62\% RMMV). This relates to the distance over which slopes were measured and variations in the specific locations where those measurements were taken.

Only two operators attempted to calculate volume for the Valdes Slide, and provided highly variable values of 0.3 and $1.3 \mathrm{~km}^{3}$. The highest measured value $\left(1.3 \mathrm{~km}^{3}\right)$ was based on an estimate of the missing volume from the scar: calculated from the difference between the scar topography and an interpolated surface that connects the upper edges of the scar (i.e. aiming to reconstruct the pre-failure topography, following the approach of ten Brink et al. 2006). The lower measured value $\left(0.3 \mathrm{~km}^{3}\right)$ was based on the landslide deposit itself.

\section{Importance of metadata to record uncertainty}

An Open Source version of the morphometric parameter inventory is hosted through a Google Fusion database. This web-based access enables the wider community to contribute morphometric data to a growing global database. In light of the challenges associated with data resolution and operator decision making, a free text metadata field accompanies the entry for each of the measured metrics to record comments on the uncertainties, errors and operator decision making involved in the data collection, analysis and measurement.

\section{Conclusions}

No common method exists for describing the morphometry of subaqueous landslides. This hinders 


\section{MORPHOMETRICS OF SUBAQUEOUS LANDSLIDES}

the effective integration of results from different research groups, disciplines and based on disparate data types. In this paper we presented and tested an approach that can be adopted to enable consistent global comparisons, and so form the basis for the compilation of a global database to integrate studies ranging from modern to ancient timescales and lacustrine to marine settings. We identified a number of challenges.

The first challenge is that a number of biases exist in data collection and analysis, spanning spatial, preservational, temporal, geographical and economic issues. These and other biases can be better recognized and addressed by a global database of subaqueous landslides. Future data collection should aim to address these issues, such as the limited data availability in margins surrounding developing countries. In the absence of margin-specific data, a consistent global database of subaqueous landslides can have a powerful role, however, by enabling the inference of information (e.g. landslide likelihood) from analogous, better-studied margins.

Second, we highlighted how the accuracy and number of parameters that can be mapped is a function of landslide scale relative to the data resolution and extents. Small landslides are difficult to map accurately (if at all) from low-resolution data, whereas large landslides may not be fully imaged by high-resolution datasets with limited extents. A global database should allow for the testing of scaling relationships on a local and global scale to provide guidance in both situations.

Finally, we presented and tested a method to enable the consistent measurement of subaqueous landslides. We found that as the degree of decision making by the operator increased, so did the uncertainty in the measured parameter. Basic parameters that describe the overall landslide scale (e.g. width, length) were most consistently measured. Parameters that required increased operator judgement (e.g. pre-failed slope, scar perimeter length) resulted in a wider range of results. We introduced a standardized method of measuring morphometry, and emphasized the importance of accompanying metadata to explain any decisions made in the measurement process to inform future comparative analysis. We feel this method of documenting subaqueous landslides will provide substantial benefits to both the research and applied community so that a consistent global landslide database can be developed.

Acknowledgements The authors thank IGCP and the S4SLIDE project (IGCP-640) for funding the workshop 'A Global Database of Subaqueous Landslides' held in London on 23-24 January 2017, and for providing travel bursaries to a number of attendees. The outcomes of the workshop motivated this paper, and we hope that it will stimulate thought, discussion and action among the broader subaqueous landslide community. This is intended to be a truly inclusive endeavour and all are invited to contribute. Any use of trade, product, or firm names is for descriptive purposes only and does not imply endorsement by the United States Government. We thank reviewers Joshu Mountjoy, Tiago Alves and the editor, Gywn Lintern, for their critical and helpful reviews that improved the manuscript and prompted useful discussions between co-authors. The open access database contribution form is hosted at https://goo.gl/o69UvY

Funding M.Clare acknowledges support from Natural Environment Research Council (grants NE/N012798/1 and NE/P009190/1). D. Gamboa acknowledges research support from the Sêr Cymru National Research Network for Low Carbon Energy and Economy and publishes with permission of the Executive Director, British Geological Survey. A. Georgiopolou acknowledges research support from the Geological Survey of Ireland Short Call grants. A Micallef acknowledges support from the European Research Council under the European Union's Horizon 2020 Programme (grant agreement No. 677898 (MARCAN)). L. Moscardelli acknowledges support from the International Geoscience Programme (IGCP) (grant IGCP-640)

\section{References}

Adams, E.W. \& Schlager, W. 2000. Basic types of submarine slope curvature. Journal of Sedimentary Research, 70, 814-828.

Alves, T.M. \& CARTwright, J.A. 2009. Volume balance of a submarine landslide in the Espírito Santo Basin, offshore Brazil: quantifying seafloor erosion, sediment accumulation and depletion. Earth and Planetary Science Letters, 2883, 572-580.

Alves, T.M., Kurtev, K., Moore, G.F. \& Strasser, M. 2014. Assessing the internal character, reservoir potential, and seal competence of mass-transport deposits using seismic texture: a geophysical and petrophysical approach. AAPG Bulletin, 98, 793-824.

Armitage, D.A., Romans, B.W., Covault, J.A. \& Graham, S.A. 2009. The influence of mass-transport-deposit surface topography on the evolution of turbidite architecture: the Sierra Contreras, Tres Pasos Formation (Cretaceous), southern Chile. Journal of Sedimentary Research, 79, 287-301.

AzPiroz-Zabala, M., Cartigny, M.J. ET AL. 2017. Newly recognized turbidity current structure can explain prolonged flushing of submarine canyons. Science Advances, 3, e1700200.

Baeten, N.J., Laberg, J.S., Forwick, M., Vorren, T.O., Vanneste, M., Forsberg, C.F. \& Ivanov, M. 2013. Morphology and origin of smaller-scale mass movements on the continental slope off northern Norway. Geomorphology, 187, 122-134.

BAUM, R.L. \& GoDT, J.W. 2010. Early warning of rainfall-induced shallow landslides and debris flows in the USA. Landslides, 7, 259-272.

Biscara, L., Hanquiez, V., Leynaud, D., Marieu, V., Mulder, T., Gallissaires, J.M. \& Garlan, T. 2012. Submarine slide initiation and evolution offshore Pointe 


\section{CLARE ET AL.}

Odden, Gabon - Analysis from annual bathymetric data (2004-2009). Marine Geology, 299, 43-50.

Brothers, D.S., Luttrell, K.M. \& Chaytor, J.D. 2013. Sea-level-induced seismicity and submarine landslide occurrence. Geology, 41, 979-982.

Calves, G., Huuse, M., Clift, P.D. \& Brusset, S. 2015 Giant fossil mass wasting off the coast of West India: the Naranja submarine slide. Earth and Planetary Science Letters, 432, 265-272.

Canals, M., Lastras, G., Urgeles, R., Casamor, J.L., Mienert, J., Cattaneo, A. \& Locat, J. 2004. Slope failure dynamics and impacts from seafloor and shallow sub-seafloor geophysical data: case studies from the COSTA project. Marine Geology, 213, 9-72.

Cardona, S., Wood, L.J., Day-Stirrat, R.J. \& MoscarDELLI, L. 2016. Fabric development and pore-throat reduction in a mass-transport deposit in the Jubilee Gas Field, Eastern Gulf of Mexico: consequences for the sealing capacity of MTDs. In: LAMARche, G., Mountjoy, J. ET AL. (eds) Submarine Mass Movements and their Consequences. Advances in Natural and Technological Hazards Research, 41. Springer, Cham, Switzerland, 27-37.

Carter, L., Gavey, R., Talling, P.J. \& Liu, J.T. 2014. Insights into submarine geohazards from breaks in subsea telecommunication cables. Oceanography, 27, 58-67.

Casas, D., Chiocci, F., Casalbore, D., Ercilla, G. \& De URBINA, J.O. 2016. Magnitude-frequency distribution of submarine landslides in the Gioia Basin (southern Tyrrhenian Sea). Geo-Marine Letters, 36, 405-414.

Cassidy, M., Trofimovs, J., Watt, S.F.L., Palmer, M.R., Taylor, R.N., Gernon, T.M. \& Le Friant, A. 2014. Multi-stage collapse events in the South Soufrière Hills, Montserrat as recorded in marine sediment cores. In: Wadge, G., Robertson, R. \& Voight, B. (eds) The Eruption of Soufrière Hills Volcano, Montserrat from 2000 to 2010. Geological Society, London, Memoirs, 39, 383-397, https://doi.org/10.1144/ M39.20

Caujapé-Castells, J., García-Verdugo, C., MarreroRodríguez, Á., Fernández-Palacios, J.M., Crawford, D.J. \& MorT, M.E. 2017. Island ontogenies, syngameons, and the origins and evolution of genetic diversity in the Canarian endemic flora. Perspectives in Plant Ecology, Evolution and Systematics, 27, 9-22.

Chaytor, J.D., Uri, S., Solow, A.R. \& Andrews, B.D. 2009. Size distribution of submarine landslides along the US Atlantic margin. Marine Geology, 264, 16-27.

Chaytor, J.D., Demopoulos, A.W., Uri, S., Baxter, C. Quattrini, A.M. \& Brothers, D.S. 2016a. Assessment of canyon wall failure process from multibeam bathymetry and Remotely Operated Vehicle (ROV) observations, US Atlantic continental margin. In: LAMARCHE, G., Mountuoy, J. ET AL. (eds) Submarine Mass Movements and their Consequences. Advances in Natural and Technological Hazards Research, 41. Springer, Cham, Switzerland, 103-113.

Chaytor, J.D., Geist, E.L., Paull, C.K., Caress, D.W., Gwiazda, R., Fucugauchi, J.U. \& Vieyra, M.R. $2016 b$. Source characterization and tsunami modeling of submarine landslides along the Yucatán Shelf/Campeche Escarpment, southern Gulf of Mexico. Pure and Applied Geophysics, 173, 4101-4116.
Chen, H. \& LeE, C.F. 2004. Geohazards of slope mass movement and its prevention in Hong Kong. Engineering Geology, 76, 3-25.

Clare, M.A., Talling, P.J., Challenor, P., Malgesini, G. \& HunT, J. 2014. Distal turbidites reveal a common distribution for large $\left(>0.1 \mathrm{~km}^{3}\right)$ submarine landslide recurrence. Geology, 42, 263-266.

Clare, M.A., Talling, P.J. \& Hunt, J.E. 2015. Implications of reduced turbidity current and landslide activity for the Initial Eocene Thermal Maximum - evidence from two distal, deep-water sites. Earth and Planetary Science Letters, 420, 102-115.

Clare, M.A., Hughes Clarke, J., Talling, P.J., Cartigny, M.J.B. \& Pratomo, D.G. 2016a. Preconditioning and triggering of offshore slope failures and turbidity currents revealed by most detailed monitoring yet at a fjord-head delta. Earth and Planetary Science Letters, 450, 208-220.

Clare, M.A., Talling, P.J., Challenor, P.G. \& Hunt, J.E. 2016b. Tempo and triggering of large submarine landslides: statistical analysis for hazard assessment. In: Lamarche, G., Mountjoy, J. et al. (eds) Submarine Mass Movements and their Consequences. Advances in Natural and Technological Hazards Research, 41. Springer, Cham, Switzerland, 509-517.

Clare, M.A., VARDY, M.E. ET AL. 2017. Direct monitoring of active geohazards: emerging geophysical tools for deep-water assessments. Near Surface Geophysics, 15, 427-444.

Clarke, S., Hubble, T. et al. 2012. Submarine landslides on the upper southeast Australian passive continental margin - preliminary findings. In: YAMADA, Y., KaWAMURA, K. ET AL. (eds) Submarine Mass Movements and their Consequences. Advances in Natural and Technological Hazards Research, 31. Springer, Dordrecht, The Netherlands, 55-66.

Collot, J.Y., Lewis, K., Lamarche, G. \& Lallemand, S. 2001. The giant Ruatoria debris avalanche on the northern Hikurangi margin, New Zealand: result of oblique seamount subduction. Journal of Geophysical Research: Solid Earth, 106, 19 271-19 297.

Coussens, M., Wall-Palmer, D. ET AL. 2016. The relationship between eruptive activity, flank collapse, and sea level at volcanic islands: a long-term ( $>1 \mathrm{Ma}$ ) record offshore Montserrat, Lesser Antilles. Geochemistry, Geophysics, Geosystems, 17, 2591-2611.

Dabson, O.J.N., Barlow, J. \& Moore, R. 2016. Morphological controls on submarine slab failures. In: Lamarche, G., Mountjoy, J. et al. (eds) Submarine Mass Movements and their Consequences. Advances in Natural and Technological Hazards Research, 41. Springer, Cham, Switzerland, 519-528.

Day, S., Llanes, P., Silver, E., Hoffmann, G., Ward, S. \& Driscoll, N. 2015. Submarine landslide deposits of the historical lateral collapse of Ritter Island, Papua New Guinea. Marine and Petroleum Geology, 67, 419-438.

Day-StirRat, R.J., Flemings, P.B., You, Y. \& van DER Pluij, B.A. 2013. Modification of mudstone fabric and pore structure as a result of slope failure: Ursa Basin, Gulf of Mexico. Marine Geology, 341, 58-67, https://doi.org/10.1016/j.margeo.2013.05.003

De Mol, B., Kozachenko, M., Wheeler, A., Alvares, H., Henriet, J.P. \& Olu-Le Roy, K. 2007. Thérèse Mound: a case study of coral bank development in the 


\section{MORPHOMETRICS OF SUBAQUEOUS LANDSLIDES}

Belgica Mound Province, Porcupine Seabight. International Journal of Earth Sciences, 96, 103-120.

Forsberg, C.F., Heyerdahl, H. \& Solheim, A. 2016. Underwater mass movements in lake Mjøsa, Norway. In: Lamarche, G., Mountjoy, J. ET AL. (eds) Submarine Mass Movements and their Consequences. Advances in Natural and Technological Hazards Research, 41. Springer, Cham, Switzerland, 191-199.

Frey-Martínez, J., Cartwright, J. \& James, D. 2006. Frontally confined versus frontally emergent submarine landslides: a 3D seismic characterisation. Marine and Petroleum Geology, 23, 585-604.

GamboA, D. \& Alves, T.M. 2016. Bi-modal deformation styles in confined mass-transport deposits: examples from a salt minibasin in SE Brazil. Marine Geology, 379, 176-193.

Gamboa, D., Alves, T. \& Cartwright, J. 2011. Distribution and characterization of failed (mega) blocks along salt ridges, southeast Brazil: implications for vertical fluid flow on continental margins. Journal of Geophysical Research, 116, B08103.

Geist, E.L. \& Parsons, T. 2006. Probabilistic analysis of tsunami hazards. Natural Hazards, 37, 277-314.

GeIst, E.L. \& PARsons, T. 2010. Estimating the empirical probability of submarine landslide occurrence. In: Mosher, D.C., Moscardelli, L., Shipp, R.C., Chaytor, J.D., BAXTER, C.D., LeE, H.J. \& URgeles, R. (eds) Submarine Mass Movements and their Consequences. Advances in Natural and Technological Hazards Research, 28. Springer, Cham, Switzerland, 377-386.

Georgiopoulou, A., Masson, D.G., Wynn, R.B. \& KrasTEL, S. 2010. Sahara Slide: age, initiation, and processes of a giant submarine slide. Geochemistry, Geophysics, Geosystems, 11, Q07014.

Georgiopoulou, A., Shannon, P.M., Sacchetti, F., Haugh TON, P.D. \& BenetTi, S. 2013. Basement-controlled multiple slope collapses, Rockall Bank slide complex, NE Atlantic. Marine Geology, 336, 198-214.

GofF, J. \& TERry, J.P. 2016. Tsunamigenic slope failures: the Pacific Islands 'blind spot'? Landslides, 13, 1535-1543.

Haflidason, H., Sejrup, H.P. et al. 2004. The Storegga Slide: architecture, geometry and slide development. Marine Geology, 213, 201-234.

Hampton, M.A., Lee, H.J. \& Locat, J. 1996. Submarine landslides. Reviews of Geophysics, 34, 33-59.

Harbitz, C.B., Løvholt, F. \& Bungum, H. 2014. Submarine landslide tsunamis: how extreme and how likely? Natural Hazards, 72, 1341-1374.

Harders, R., Ranero, C.R., Weinrebe, W. \& Behrmann, J.H. 2011. Submarine slope failures along the convergent continental margin of the Middle America Trench. Geochemistry, Geophysics, Geosystems, 12, Q05S32.

Haughton, P., Davis, C., McCaffrey, W. \& Barker, S. 2009. Hybrid sediment gravity flow deposits-classification, origin and significance. Marine and Petroleum Geology, 26, 1900-1918.

He, Y., Zhong, G., Wang, L. \& Kuang, Z. 2014. Characteristics and occurrence of submarine canyon-associated landslides in the middle of the northern continental slope, South China Sea. Marine and Petroleum Geology, 57, 546-560.

Henry, L.C., Wadsworth, J.A. \& Hansen, B. 2017. Visualizing a sub-salt field with image logs: image facies, mass transport complexes, and reservoir implications from Thunder Horse, Mississippi canyon, Gulf of Mexico. Search and Discovery Article \#90291, AAPG Annual Convention and Exhibition, 2-5 April 2017, Houston, Texas, USA.

Hilton, R.G., Galy, A. \& Hovius, N. 2008. Riverine particulate organic carbon from an active mountain belt: importance of landslides. Global Biogeochemical Cycles, 22, GB1017.

Hu, G., Yan, T., Liu, Z., Vanneste, M. \& Dong, L. 2009. Size distribution of submarine landslides along the middle continental slope of the East China Sea. Journal of Ocean University of China (English Edition), 8 , 322-326.

Hughes Clarke, J.E. 2018. Multibeam echosounders. In: Micallef, A., KRastel, S. \& SAvini, A. (eds) Submarine Geomorphology. Springer, Cham, Switzerland, 25-41.

Hughes Clarke, J.E., Marques, C.R.V. \& Pratomo, D 2014. Imaging active mass-wasting and sediment flows on a fjord delta, Squamish, British Columbia. In: Krastel, S., Behrmann, J.-H. et al. (eds) Submarine Mass Movements and their Consequences. Advances in Natural and Technological Hazards Research, 37. Springer, Berlin, 249-260.

HüHneRbach, V. \& Masson, D.G. 2004. Landslides in the North Atlantic and its adjacent seas: an analysis of their morphology, setting and behaviour. Marine Geology, 213, 343-362.

Hungr, O., Leroueit, S. \& Picarelli, L. 2014. The Varnes classification of landslide types, an update. Landslides, 11, 167-194.

Hunt, J.E., Talling, P.J., Clare, M.A., Jarvis, I. \& Wynn, R.B. 2014. Long term (17 Ma) turbidite record of the timing and frequency of large flank collapses of the Canary Islands. Geochemistry, Geophysics, Geosystems, 15, 3322-3345.

Huvenne, V.A., Georgiopoulou, A., Chaumillon, L., Iacono, C.L. \& WynN, R.B. 2016. Novel method to map the morphology of submarine landslide headwall scarps using Remotely Operated Vehicles. In: Lamarche, G., Mountjoy, J. et al. (eds) Submarine Mass Movements and their Consequences. Advances in Natural and Technological Hazards Research, 41. Springer, Cham, Switzerland, 135-144.

Huvenne, V.A., Robert, K., Marsh, L., Iacono, C.L., Le BAS, T. \& WYNN, R.B. 2018. ROVs and AUVs. In Micallef, A., Krastel, S. \& Savini, A. (eds) Submarine Geomorphology. Springer, Cham, Switzerland, 93-108.

Katz, O., Reuven, E. \& Aharonov, E. 2015. Submarine landslides and fault scarps along the eastern Mediterranean Israeli continental-slope. Marine Geology, $\mathbf{3 6 9}$, 100-115.

KeEFER, D.K. 1984. Landslides caused by earthquakes. Geological Society of America Bulletin, 95, 406-421.

Kelner, M., Migeon, S., Tric, E., Couboulex, F., Dano, A., Lebourg, T. \& TABoadA, A. 2016. Frequency and triggering of small-scale submarine landslides on decadal timescales: analysis of 4D bathymetric data from the continental slope offshore Nice (France). Marine Geology, 379, 281-297.

Kirschbaum, D.B., Adler, R., Hong, Y., Hill, S. \& LERNER-LAM, A. 2010. A global landslide catalog for hazard applications: method, results, and limitations. Natural Hazards, 52, 561-575. 


\section{CLARE ET AL.}

Klose, M., Gruber, D., Damm, B. \& Gerold, G. 2014. Spatial databases and GIS as tools for regional landslide susceptibility modeling. Zeitschrift für Geomorphologie, 58, 1-36.

Kneller, B., Dykstra, M., Fairweather, L. \& Milana, P. 2016. Mass-transport and slope accommodation: implications for turbidite sandstone reservoir. $A A P G$ Bulletin, 100, 213-235.

Korup, O., Clague, J.J., Hermanns, R.L., Hewitt, K., Strom, A.L. \& Weidinger, J.T. 2007. Giant landslides, topography, and erosion. Earth and Planetary Science Letters, 261, 578-589.

Krastel, S., Behrmann, J.-H. et al. (eds). 2014. Submarine Mass Movements and their Consequences. Advances in Natural and Technological Hazards Research, 37. Springer, Berlin.

KREMER, K., WIRTH, S.B. ET AL. 2017. Lake-sediment based paleoseismology: limitations and perspectives from the Swiss Alps. Quaternary Science Reviews, 168, 1-18.

Laberg, J.S. \& VorRen, T.O. 2000. The Trænadjupet Slide, offshore Norway - morphology, evacuation and triggering mechanisms. Marine Geology, 171, 95-114.

Lacoste, A., Vendeville, B.C., Mourgues, R., Loncke, L. \& LEBACQ, M. 2012. Gravitational instabilities triggered by fluid overpressure and downslope incision - insights from analytical and analogue modelling. Journal of Structural Geology, 42, 151-162.

Lamarche, G., Mountjoy, J. et al. (eds) 2016. Submarine Mass Movements and their Consequences. Advances in Natural and Technological Hazards Research, 41. Springer, Cham, Switzerland.

Li, W., Alves, T.M. ET AL. 2017. Morphology, age and sediment dynamics of the upper headwall of the Sahara Slide Complex, Northwest Africa: evidence for a large Late Holocene failure. Marine Geology, 393, 109-123, https://doi.org/10.1016/j.margeo.2016.11.013

LindBeRG, B., LABERG, J.S. \& VorRen, T.O. 2004. The Nyk Slide - morphology, progression, and age of a partly buried submarine slide offshore northern Norway. Marine Geology, 213, 277-289.

LOCAT, J. \& LEE, H.J. 2002. Submarine landslides: advances and challenges. Canadian Geotechnical Journal, 39, 193-212.

Lykousis, V., Sakellariou, D. \& Locat, J. (eds) 2007. Submarine Mass Movements and their Consequences. Advances in Natural and Technological Hazards Research, 27. Springer, Cham, Switzerland.

Madhusudhan, B.N., Clare, M.A., Clayton, C.R.I. \& HunT, J.E. 2017. Geotechnical profiling of deep-ocean sediments at the AFEN submarine slide complex. Quarterly Journal of Engineering Geology and Hydrogeology, 50, 148-157, https://doi.org/10.1144/qjegh2016-057

Maia, A.R., Cartwright, J., Andersen, E. \& Gamboa, D. 2015. Fluid flow within MTDs: evidences of fluid storage and leakage from 3D seismic data, offshore West Africa. Presented at the 7th International Symposium Submarine Mass Movements and their Consequences, 1-4 November 2015, Wellington, New Zealand.

Malamud, B.D., Turcotte, D.L., Guzzetti, F. \& ReichenBACH, P. 2004. Landslide inventories and their statistical properties. Earth Surface Processes and Landforms, 29, 687-711.

MANDELBRot, B.B. 1967. How long is the coast of Britain? Science, 156, 636-638
Masson, D.G. 1996. Catastrophic collapse of the volcanic island of Hierro $15 \mathrm{ka}$ ago and the history of landslides in the Canary Islands. Geology, 24, 231-234.

Masson, D.G., Harbitz, C.B., Wynn, R.B., Pedersen, G. \& Løvноцт, F. 2006. Submarine landslides: processes, triggers and hazard prediction. Philosophical Transactions of the Royal Society of London A: Mathematical, Physical and Engineering Sciences, 364, 2009-2039.

Mastbergen, D., van den Ham, G. et al. 2016. Multiple flow slide experiment in the Westerschelde Estuary, The Netherlands. In: Lamarche, G., Mountjoy, J. ET AL. (eds) Submarine Mass Movements and their Consequences. Advances in Natural and Technological Hazards Research, 41. Springer, Cham, Switzerland, 241-249.

McAdoo, B.G., Pratson, L.F. \& Orange, D.L. 2000. Submarine landslide geomorphology, US continental slope. Marine Geology, 169, 103-136.

MECKEL, L., III. 2011. Reservoir characteristics and classification of sand-prone submarine mass-transport deposits. In: Shipp, R.C., Weimer, P. \& Posamentier, H. (eds) Mass-Transport Deposits in Deepwater Settings. SEPM Special Publications, 96, 423-452.

Micallef, A., Berndt, C., Masson, D.G. \& Stow, D.A. 2007. A technique for the morphological characterization of submarine landscapes as exemplified by debris flows of the Storegga Slide. Journal of Geophysical Research: Earth Surface, 112, F02001.

Micallef, A., Mountuoy, J.J., Canals, M. \& Lastras, G. 2012. Deep-seated bedrock landslides and submarine canyon evolution in an active tectonic margin: Cook Strait, New Zealand. In: Yamada, Y., Kawamura, K. ET AL. (eds) Submarine Mass Movements and their Consequences. Advances in Natural and Technological Hazards Research, 31. Springer, Dordrecht, The Netherlands, 201-212.

Mienert, J. 2004. COSTA - continental slope stability: major aims and topics. Marine Geology, 213, 1-7.

Moernaut, J. \& De Batist, M. 2011. Frontal emplacement and mobility of sublacustrine landslides: results from morphometric and seismostratigraphic analysis. Marine Geology, 285, 29-45.

Moernaut, J., Van Daele, M. et al. 2017. Lacustrine turbidites produced by surficial slope sediment remobilization: a mechanism for continuous and sensitive turbidite paleoseismic records. Marine Geology, 384, $159-176$

Moore, J.G., Clague, D.A., Holcomb, R.T., Lipman, P.W., Normark, W.R. \& Torresan, M.E. 1989. Prodigious submarine landslides on the Hawaiian Ridge. Journal of Geophysical Research: Solid Earth, 94, 17 465-17 484.

Moore, J.G., Normark, W.R. \& Holcomb, R.T. 1994. Giant hawaiian landslides. Annual Review of Earth and Planetary Sciences, 22, 119-144.

Moore, R., Davis, G. \& Dabson, O. 2018. Applied geomorphology and geohazard assessment for deepwater development. In: Micallef, A., Krastel, S. \& Savini, A. (eds) Submarine Geomorphology. Springer, Cham, Switzerland, 459-479.

Moscardelli, L. \& Wood, L. 2008. New classification system for mass transport complexes in offshore Trinidad. Basin Research, 20, 73-98. 


\section{MORPHOMETRICS OF SUBAQUEOUS LANDSLIDES}

Moscardelli, L. \& Wood, L. 2016. Morphometry of mass-transport deposits as a predictive tool. Geological Society of America Bulletin, 128, 47-80.

Mosher, D.C., Moscardelli, L., Shipp, R.C., Chaytor, J.D., Baxter, C.D., Lee, H.J. \& Urgeles, R. (eds) 2010a. Submarine Mass Movements and their Consequences. Advances in Natural and Technological Hazards Research, 28. Springer, Cham, Switzerland.

Mosher, D.C., Moscardelli, L., Shipp, R.C., Chaytor, J.D., Baxter, C.D., Lee, H.J. \& Urgeles, R. $2010 b$. In: Mosher, D.C., Moscardelli, L., Shipp, R.C., Chaytor, J.D., Baxter, C.D., Lee, H.J. \& Urgeles, R. (eds) Submarine Mass Movements and their Consequences. Advances in Natural and Technological Hazards Research, 28. Springer, Cham, Switzerland, $1-8$.

Mosher, D.C., Laberg, J.S. \& Murphy, A. 2016. The role of submarine landslides in the Law of the Sea. In: Lamarche, G., Mountjoy, J. ET aL. (eds) Submarine Mass Movements and their Consequences. Advances in Natural and Technological Hazards Research, 41. Springer, Cham, Switzerland, 15-26.

Mountjoy, J. \& Micallef, A. 2018. Submarine landslides. In: Micallef, A., Krastel, S. \& Savini, A. (eds) Submarine Geomorphology. Springer, Cham, Switzerland, 235-250.

Mountjoy, J.J., Pecher, I., Henrys, S., Crutchley, G., Barnes, P.M. \& Plaza-Faverola, A. 2014. Shallow methane hydrate system controls ongoing, downslope sediment transport in a low-velocity active submarine landslide complex, Hikurangi Margin, New Zealand. Geochemistry, Geophysics, Geosystems, 15, 4137-4156.

Mulder, T. \& Cochonat, P. 1996. Classification of offshore mass movements. Journal of Sedimentary Research, 66 , 43-57.

NitTrouer, C.A. 1999. STRATAFORM: overview of its design and synthesis of its results. Marine Geology, 154, 3-12.

Normandeau, A., CampBell, D.C. ET AL. In press. Extensive submarine landslide on the west levee of the Laurentian Fan: an exceptional deep-water event during the Quaternary? In: Lintern, D.G., Mosher, D.C. ET AL. (eds) Subaqueous Mass Movements. Geological Society, London, Special Publications, 477, https://doi.org/ 10.1144/SP477.14

Obelcz, J., Xu, K., Georgiou, I.Y., Maloney, J., Bentley, S.J. \& MineR, M.D. 2017. Sub-decadal submarine landslides are important drivers of deltaic sediment flux: insights from the Mississippi River Delta Front. Geology, 45, 703-706.

Ogiesoba, O. \& Hammes, U. 2012. Seismic interpretation of mass-transport deposits within the upper Oligocene Frio Formation, south Texas Gulf Coast. AAPG Bulletin, 96, 845-868.

OKey, T.A. 1997. Sediment flushing observations, earthquake slumping, and benthic community changes in Monterey Canyon head. Continental Shelf Research, 17, 877-897.

Owen, M., Day, S. \& Maslin, M. 2007. Late Pleistocene submarine mass movements: occurrence and causes. Quaternary Science Reviews, 26, 958-978.

Paull, C.K., Schlining, B., Ussler, W., III, Lundste, E., Barry, J.P., Caress, D.W. \& McGann, M. 2010.
Submarine mass transport within Monterey Canyon: benthic disturbance controls on the distribution of chemosynthetic biological communities. In: Mosher, D.C., Moscardelli, L., Shipp, R.C., Chaytor, J.D., BAXTER, C.D., LeE, H.J. \& URGELES, R. (eds) Submarine Mass Movements and their Consequences. Advances in Natural and Technological Hazards Research, 28. Springer, Cham, Switzerland, 229-246.

Pennington, C., Freeborough, K., Dashwood, C., DijkStra, T. \& Lawrie, K. 2015. The National Landslide Database of Great Britain: acquisition, communication and the role of social media. Geomorphology, 249, 44-51.

Petley, D. 2012. Global patterns of loss of life from landslides. Geology, 40, 927-930.

Petley, D.N., Dunning, S.A. \& Rosser, N.J. 2005. The Analysis of Global Landslide Risk through the Creation of a Database of Worldwide Landslide Fatalities. Landslide Risk Management. A.A. Balkema, Amsterdam.

PIPER, D.J. \& NoRmark, W.R. 2009. Processes that initiate turbidity currents and their influence on turbidites: a marine geology perspective. Journal of Sedimentary Research, 79, 347-362.

Piper, D.J., Cochonat, P. \& Morrison, M.L. 1999. The sequence of events around the epicentre of the 1929 Grand Banks earthquake: initiation of debris flows and turbidity current inferred from sidescan sonar. Sedimentology, 46, 79-97.

Pope, E.L., Talling, P.J., Urlaub, M., Hunt, J.E., Clare, M.A. \& Challenor, P. 2015. Are large submarine landslides temporally random or do uncertainties in available age constraints make it impossible to tell? Marine Geology, 369, 19-33.

Pope, E.L., TAlling, P.J. \& CARTER, L. 2016. Which earthquakes trigger damaging submarine mass movements: insights from a global record of submarine cable breaks? Marine Geology, 384, 131-146.

Pope, E.L., Talling, P.J., Carter, L., Clare, M.A. \& Hunt, J.E. 2017. Damaging sediment density flows triggered by tropical cyclones. Earth and Planetary Science Letters, 458, 161-169.

Praet, N., Moernaut, J. et al. 2017. Paleoseismic potential of sublacustrine landslide records in a high-seismicity setting (south-central Alaska). Marine Geology, 384, 103-119.

PuzRIN, A.M. 2016. Simple criteria for ploughing and runout in post-failure evolution of submarine landslides. Canadian Geotechnical Journal, $\mathbf{5 3}$ 1305-1314.

Riboulot, V., Cattaneo, A., Sultan, N., Garziglia, S., Ker, S., Imbert, P. \& Voisset, M. 2013. Sea-level change and free gas occurrence influencing a submarine landslide and pockmark formation and distribution in deepwater Nigeria. Earth and Planetary Science Letters, 375, 78-91.

Richardson, S.E., Davies, R.J., Allen, M.B. \& Grant, S.F. 2011. Structure and evolution of mass transport deposits in the South Caspian Basin, Azerbaijan. Basin Research, 23, 702-719.

Savini, A., Marchese, F., Verdicchio, G. \& Vertino, A. 2016. Submarine slide topography and the distribution of vulnerable marine ecosystems: a case study in the Ionian Sea (Eastern Mediterranean). In: LAMARche, 


\section{CLARE ET AL.}

G., Mountuoy, J. ET AL. (eds) Submarine Mass Movements and their Consequences. Advances in Natural and Technological Hazards Research, 41. Springer, Cham, Switzerland, 163-170.

Sawyer, D.E. \& DeVore, J.R. 2015. Elevated shear strength of sediments on active margins: evidence for seismic strengthening. Geophysical Research Letters, 42, 10,216-10,221.

Smith, D.P., Kvitek, R., IAmpietro, P.J. \& Wong, K. 2007. Twenty-nine months of geomorphic change in upper Monterey Canyon (2002-2005). Marine Geology, 236, 79-94.

Smith, R.W., Bianchi, T.S., Allison, M., Savage, C. \& Galy, V. 2015. High rates of organic carbon burial in fjord sediments globally. Nature Geoscience, 8, 450-453.

Solheim, A. 2006. Submarine mass movements and their consequences, 2nd international symposium: summary. Norwegian Journal of Geology, 86, 151-154.

St-Onge, G. \& Hillaire-Marcel, C. 2001. Isotopic constraints of sedimentary inputs and organic carbon burial rates in the Saguenay Fjord, Quebec. Marine Geology, 176, 1-22.

Strasser, M., Monecke, K., Schnellmann, M. \& AnselMETTI, F.S. 2013. Lake sediments as natural seismographs: a compiled record of Late Quaternary earthquakes in Central Switzerland and its implication for Alpine deformation. Sedimentology, 60, 319-341.

Strupler, M., Hilbe, M., Anselmetti, F.S., Kopf, A.J., Fleischmann, T. \& Strasser, M. 2017. Probabilistic stability evaluation and seismic triggering scenarios of submerged slopes in Lake Zurich (Switzerland). GeoMarine Letters, 37, 241-258.

Swanson, F.J., Kratz, T.K., Caine, N. \& Woodmansee, R.G. 1988. Landform effects on ecosystem patterns and processes. BioScience, 38, 92-98.

Symons, W.O., Sumner, E.J., Talling, P.J., Cartigny, M.J. \& CLARE, M.A. 2016. Large-scale sediment waves and scours on the modern seafloor and their implications for the prevalence of supercritical flows. Marine Geology, 371, 130-148.

TAlling, P.J., WynN, R.B. ET AL. 2007. Onset of submarine debris flow deposition far from original giant landslide. Nature, 450, 541-544.

Talling, P.J., Clare, M.L., Urlaub, M., Pope, E., Hunt, J.E. \& WATT, S.F. 2014. Large submarine landslides on continental slopes: geohazards, methane release, and climate change. Oceanography, 27, 32-45.

TAPPIN, D.R., WatTs, P., McMurtry, G.M., Lafoy, Y. \& Matsumoto, T. 2001. The Sissano, Papua New Guinea tsunami of July 1998 - offshore evidence on the source mechanism. Marine Geology, 175, 1-23.

Taylor, F.E., Malamud, B.D., Freeborough, K. \& DemerITT, D. 2015. Enriching Great Britain's national landslide database by searching newspaper archives. Geomorphology, 249, 52-68.

ten Brink, U.S., Geist, E.L. \& Andrews, B.D. 2006. Size distribution of submarine landslides and its implication to tsunami hazard in Puerto Rico. Geophysical Research Letters, 33, L11307, https://doi.org/10. 1029/2006GL026125

ten Brink, U.S., Barkan, R., Andrews, B.D. \& Chaytor, J.D. 2009. Size distributions and failure initiation of submarine and subaerial landslides. Earth and Planetary Science Letters, 287, 31-42.
TEN Brink, U.S., Andrews, B.D. \& Miller, N.C. 2016. Seismicity and sedimentation rate effects on submarine slope stability. Geology, 44, 563-566.

Terry, J.P., Winspear, N., GofF, J. \& Tan, P.H. 2017. Past and potential tsunami sources in the South China Sea: a brief synthesis. Earth-Science Reviews, 167, 47-61, https://doi.org/10.1016/j.earscirev.2017.02.007

Thomas, S., Hooper, J. \& Clare, M. 2010. Constraining geohazards to the past: impact assessment of submarine mass movements on seabed developments. In: MosHer, D.C., Moscardelli, L., Shipp, R.C., Chaytor, J.D., BaXter, C.D., Lee, H.J. \& Urgeles, R. (eds) Submarine Mass Movements and their Consequences. Advances in Natural and Technological Hazards Research, 28. Springer, Cham, Switzerland, 387-398.

Twichell, D.C., Chaytor, J.D., Uri, S. \& Buczkowski, B. 2009. Morphology of late Quaternary submarine landslides along the US Atlantic continental margin. Marine Geology, 264, 4-15.

Urgeles, R. \& CAmerlenghi, A. 2013. Submarine landslides of the Mediterranean Sea: trigger mechanisms, dynamics, and frequency-magnitude distribution. Journal of Geophysical Research: Earth Surface, 118, 2600-2618.

Urlaub, M., Talling, P.J. \& Masson, D.G. 2013. Timing and frequency of large submarine landslides: implications for understanding triggers and future geohazard. Quaternary Science Reviews, 72, 63-82.

Urlaub, M., Talling, P. \& Clare, M. 2014. Sea-levelinduced seismicity and submarine landslide occurrence: comment. Geology, 42, e337.

URLAUB, M. ET AL. 2018. In situ monitoring of submarine landslides using seabed instruments. In: LiNTERN, D.G., Mosher, D.C. eT AL. (eds) Subaqueous Mass Movements. Geological Society, London, Special Publications, 477, https://doi.org/10.1144/SP477.8

Van Daele, M., Moernaut, J. et AL. 2015. A comparison of the sedimentary records of the 1960 and 2010 great Chilean earthquakes in 17 lakes: implications for quantitative lacustrine palaeoseismology. Sedimentology, 62, 1466-1496.

Vanneste, M., Sultan, N., Garziglia, S., Forsberg, C.F. \& L'HeureuX, J.S. 2014. Seafloor instabilities and sediment deformation processes: the need for integrated, multi-disciplinary investigations. Marine Geology, 352, 183-214.

VARNES, D.J. 1958. Landslide types and processes. Landslides and Engineering Practice, 24, 20-47.

Völker, D., Geersen, J., Behrmann, J.H. \& Weinrebe, W.R. 2012. Submarine mass wasting off Southern Central Chile: distribution and possible mechanisms of slope failure at an active continental margin. In: Yamada, Y., Kawamura, K. ET al. (eds) Submarine Mass Movements and their Consequences. Advances in Natural and Technological Hazards Research, 31. Springer, Dordrecht, The Netherlands, 379-389.

WalKer, L.R., Velázquez, E. \& Shiels, A.B. 2009. Applying lessons from ecological succession to the restoration of landslides. Plant and Soil, 324, 157-168.

WARD, S.N. 2001. Landslide tsunami. Journal of Geophysical Research: Solid Earth, 106, 11201-11215.

WatTs, A.B. \& MAsson, D.G. 1995. A giant landslide on the north flank of Tenerife, Canary Islands. Journal of Geophysical Research: Solid Earth, 100, 24487-24498. 


\section{MORPHOMETRICS OF SUBAQUEOUS LANDSLIDES}

WynN, R.B. \& STOw, D.A. 2002. Classification and characterisation of deep-water sediment waves. Marine Geology, 192, 7-22.

Wynn, R.B., Huvenne, V.A. ET AL. 2014. Autonomous Underwater Vehicles (AUVs): their past, present and future contributions to the advancement of marine geoscience. Marine Geology, 352, 451-468.
Yamada, Y., KawamuRa, K. ET AL. 2012. Submarine mass movements and their consequences. In: Yamada, Y., Kawamura, K. et al. (eds) Submarine Mass Movements and their Consequences. Advances in Natural and Technological Hazards Research, 31. Springer, Dordrecht, The Netherlands, $1-12$. 